Review article/Pregledni znanstveni članek

\title{
Use of cutting-edge biomedical devices for intravenous cannulation in the health care of a patient: literature review
}

Uporaba sodobnih biomedicinskih pripomočkov za vzpostavljanje periferne venske poti v zdravstveni oskrbi pacienta: pregled literature

\author{
Zvonka Fekonja, Majda Pajnkihar
}

Key words: biomedical devices; intravenous cannula; nursing; difficult venous access

Ključne besede: biomedicinski pripomočki; intravenska kanila; zdravstvena nega; otežen venski dostop

Assistant Zvonka Fekonja, MSN, BSc, RN; University of Maribor, Faculty of Health Sciences, Žitna ulica 15, 2000 Maribor, Slovenia

Correspondence e-mail/ Kontaktni e-naslov: zvonka.fekonja@um.si

Associate Professor Majda Pajnkihar, $\mathrm{PhD}, \mathrm{MSc}, \mathrm{BSc}, \mathrm{RN}$; University of Maribor, Faculty of Health Sciences, Žitna ulica 15, 2000 Maribor, Slovenia and University of Maribor, Faculty of Medicine, Taborska ulica 8, 2000 Maribor, Slovenia

\section{ABSTRACT}

Introduction: Biomedical devices are tools used for locating invisible and impalpable peripheral veins. The purpose of this article is to give a systematic review and analysis of existing studies on the available biomedical devices used for locating peripheral veins and on their effectiveness in clinical practice.

Methods: Databases CINAHL, Medline and ScienceDirect were used for the literature review and analysis. The search was performed with the following key words in English: devices, visualization, technology, cannulation, vein, nursing care, with Boolean operators 'AND' and 'OR'. The analysis included randomized and experimental clinical studies published in the English language in the period from 2000 to August 2016. From a total of 1,020 retrieved studies, 17 were included in the detailed analysis.

Results: The results of the analysis have shown that the success rate of the first attempt of intravenous cannulation using biomedical devices in more than half of the studies was not significantly higher than when the process was performed using the conventional method. The success of the first attempt of intravenous cannulation mostly depends on the experience and skills of nurses. Biomedical devices are more helpful for novice nurses who do not perform cannulation on a daily basis, for beginners and nursing students.

Discussion and conclusions: Based on research, we cannot affirm that biomedical devices significantly contribute to easier peripheral venous cannulation. Further research is required to validate the advantages of such an approach. However, this is limited due to the affordability issues of such biomedical devices.

\section{IZVLEČEK}

Uvod: Biomedicinski pripomočki za vstavljanje intravenske kanile so danes pomemben del opreme, ki naj bi jo medicinske sestre uporabljale pri svojem delu. Namen članka je sistematičen pregled obstoječih raziskav o razpoložljivih biomedicinskih pripomočkih za iskanje perifernih ven, pogostnost in koristnost njihove uporabe v klinični praksi.

Metode: Za pregled literature in analizo virov so bile uporabljene zbirke podatkov CINAHL, MEDLINE in ScienceDirect. Iskanje je bilo izvedeno $\mathrm{z}$ naslednjimi angleškimi ključnimi besedami in njihovimi sopomenkami, povezanimi z Boolovima operatorjema AND oz. OR: »devices«, »visualization «, »technology«, "cannulation«, "vein«, »nursing care«. V analizo so bile vključene ekperimentalne in neeksperimentalne klinične raziskave, objavljene od leta 2000 do avgusta $2016 \mathrm{v}$ angleškem jeziku. Iz iskalnega nabora 1020 zadetkov je bilo v končno analizo vključenih 17 raziskav.

Rezultati: Rezultati so pokazali, da uspešnost prvega poskusa vstavljanja intravenske kanile z biomedicinskimi pripomočki pri večkot polovici raziskav ni značilno višja od konvencionalne metode. Uspešnost prvega poskusa vstavljanja je odvisna predvsem od izkušenosti in spretnosti medicinske sestre. Biomedicinski pripomočki so dragocena pomoč neizkušenim medicinskim sestram, ki venepunkcije ne izvajajo vsakodnevno, začetnicam in študentom zdravstvene nege.

Diskusija in zaključek: Na podlagi raziskave ne moremo z gotovostjo trditi, da biomedicinski pripomočki bistveno pripomorejo $\mathrm{k}$ lažji vzpostavitvi perifernega venskega kanala. Za potrjevanje prednosti takšnega pristopa bodo potrebna nadaljnja raziskovanja, vendar pa so le-ta omejena $\mathrm{z}$ majhno dostopnostjo biomedicinskih pripomočkov. 


\section{Introduction}

Establishing peripheral venous access is a routine invasive procedure, which is performed on approximately $70 \%$ of patients during hospitalisation (Bernatchez, 2014). Peripheral venous line refers to the insertion of various plastic needles or catheters in the peripheral vain. Establishing peripheral venous access is one of the most frequently performed interventional procedures in nursing care (Bauman, et al., 2009; Walsh, 2008; Juric \& Zalik, 2014) and is one of the most invasive procedures for patients who seek help in an emergency department (Bernatchez, 2014). The peripheral venous line is important for a critically ill patient due to the need for blood sampling for laboratory testing, medicine administration, and fluid or parenteral infusion, which a patient might need in a given moment (Alekseyev, et al., 2012). Insertion of peripheral venous cannula is a skill that a competent registered nurse has (Strgar \& Macura Višić, 2013). The patient's medical condition plays an important role in establishing venous access. Risk factors and the patient medical conditions which may result in difficult vein access include the patient's age, experience of the person performing the procedure, the size of the cannula and the site of insertion (Chinnock, et al., 2007; Sebbane, et al., 2013; Heinrichs, et al., 2013). In addition, there are some characteristic groups of patients with whom establishing a peripheral venous line is more difficult: obese patients, patients with peripheral oedema, patients undergoing chemotherapy, intravenous drug abusers, severely dehydrated patients (Gregg, et al., 2010; Fields, et al., 2014), dark skinned patients (Aulagnier, et al., 2014), as well as children and the elderly (Walsh, 2008). Lack of skill, inept nurses or difficult intravenous access contribute to the need for repeated attempts of insertion (Walsh, 2008). Cuper and colleagues (2010) have found that while the risk factors are well known in practice, they are quite poorly described in the literature. There is a higher probability that difficulties arise when performing cannulation in children younger than two years and particularly in infants (Chapman, et al., 2011; Heinrichs, et al., 2013). Arbique and colleagues (2014) think that a successful insertion of intravenous cannula requires the operator to be familiar with the vein and endothelial cell anatomy, as well as the names and sites most appropriate for venepuncture of the most suitable peripheral veins; the operator should know before the first attempt of insertion why the intravenous cannula is necessary and which vein is most suitable for venepuncture. Furthermore, the operator should also be familiar with the complications related to a damaged vein caused by the application of medicines or fluid administration. When the nursing staff understand these mentioned key elements, their knowledge may decrease the chances of causing the patient unnecessary pain or discomfort as a result of several unsuccessful attempts of intravenous cannulation, less delays in medical care, decreased use of expensive biomedical equipment, as well as less non-productively used time in nursing and thus a general improvement of nursing care.

To supplement the standard procedure of blind intravenous cannulation, procedures based on additional visualisation of subcutaneous veins have been developed: use of ultrasound devices, transillumination (illumination of the peripheral parts of the human body with other sources of light - with red or white light) and biomedical devices for near infrared spectroscopy. Biomedical devices were developed with the purpose of improving the success rate of venepuncture and consequently reducing the number and scope of the negative effects of multiple or unsuccessful cannulation, and with the additional purpose of avoiding the frustrations of health care workers in cases of unsuccessful intervention. In comparison to the conventional method of establishing the peripheral venous channel, the use of biomedical devices has several advantages as it enables the placement of intravenous cannula in veins that are invisible and impalpable, thus eliminating the need to establish a central peripheral line, which in turn decreases the risk of infection and other complications (Sirk, et al., 2013). Early identification of patients with risk factors for a difficult establishment of the peripheral venous line is important because it offers the chance to adjust the strategy in order to increase the success rate or a critical evaluation of employing alternative methods for establishing peripheral venous line or venous devices (Walsh, 2008; Pagnutti, et al., 2016).

The oldest technique used for the visualisation of subcutaneous veins is called transillumination, which involves placing sources of light under or around the selected limb (John, 2007). The use of near infrared spectroscopy (NIR) is relatively new and includes a direct illumination and visualisation of the venepuncture site (Fukuroku, et al., 2016). Due to a higher content of deoxygenated haemoglobin, subcutaneous veins are nearly entirely absorbed in infrared light (IR) with a wavelength between $740 \mathrm{~nm}$ to $760 \mathrm{~nm}$, while the arteries almost completely translucent due to a higher content of oxygenated haemoglobin. The mentioned interval of the wavelength belongs to the so called near infrared area encompassing the wavelength from $700 \mathrm{~nm}$ to 1400 $\mathrm{nm}$ (Juric, et al., 2014). Based on the available literature the following devices are available on the market: VascuLuminator $^{\circledR}$ (Cuper, et al., 2013), VeinViewer ${ }^{\circledR}$ in Wee Sight ${ }^{\circledR}$ (Peterson, et al., 2012), AccuVein ${ }^{\circledR}$ (Kaddoum, et al., 2012), VenoScope ${ }^{\circledR}$, VeinLocator ${ }^{\circledR}$ in VeinLite $^{\circledR}$ (Ernst, 2009) and Veinsite ${ }^{\circledR}$ (Chiao, et al., 2013).

The mentioned biomedical devices differ in their approach of visualising the veins and use of various components. The VeinViewer ${ }^{\circledR}$ device with NIR light analyses the skin and projects the received image back on the skin, whereby the veins are visible as black lines on a green background (Hess, 2010). This image serves 
as a kind of map for the nurse to use, hence making them more efficient at cannulation (Lamperti \& Pittiruti, 2013). The advantage of using this device is that the operator may look straight at the site of the cannulation while performing the puncture, however, the normal view of the site of insertion is changed and this technique requires the image to be processed as it can be sensitive to outside influences (Miyake, et al., 2006). The AccuVein ${ }^{\circledR}$ device functions in a similar way, but it projects the veins as black lines on a red background (Cuper, et al., 2013). The VascuLuminator ${ }^{\circledR}$ device is different as the NIR light is placed under the insertion site, while the insertion site is visible on the screen where the veins are black on a light background (Cuper, et al., 2013). The insertion site should therefore be observed on the screen where an image is projected through a camera (Dunn \& Conrad, 2005). A review and analysis of the market have revealed that there are other devices being developed which focus on the issue of difficult venepuncture. Such devices are: Evena Eyes-On Glasses ${ }^{\circledR}$ (Medical, 2015), EasyVein ${ }^{\circledR}$ (InSono, 2015), Vein Display ${ }^{\circledR}$ (Fukuroku, et al., 2016) in mVeinVison ${ }^{\circledR}$, which enables visualisation of subcutaneous veins on mobile devices with the Android operational system (Juric \& Zalik, 2014).

\section{Aims and objectives}

The purpose of this article is to present the results of a systematic review and data analysis of existing research on the available biomedical devices that are based on using NIR light to locate peripheral veins. A review of presently available devices and the results of their use in clinical practice are presented.

\section{Methods}

We used a five-step methodological approach as described by Higgins and Green (2009). This approach encompasses setting a research question, setting suitability criteria, searching for relevant evidence, critically reviewing collected data, and analysing and synthesising results. We set a specific research question using the PICO (Population, Intervention, Comparison, Outcome) (Melnyk \& Fineout-Overholt, 2015) approach for literature review: To what extent does using cuttingedge biomedical devices based on near infrared spectroscopy affect the success rate of the first attempt of peripheral venous cannulation in comparison to the conventional peripheral venous cannulation method in patients with a difficult venous access?

\section{Review methods}

We conducted a systematic literature review as it enables the obtainment of data from various sources and ensures a holistic understanding of the research subject. The literature search was conducted in the following databases: CINAHL, MEDLINE and
ScienceDirect by means of several combinations of selected search words in the English language, and their synonyms, with Boolean operators AND or OR: 'devices', 'visualization', 'technology', 'cannulation', 'vein', and 'nursing care'. The criterion in selecting the literature was that articles were published in the period from 2000 to August 2016.

In addition to the language and publication time restriction, the main inclusion factors were also peerreview, quantitative research, subject focus, the use and functions of biomedical devices for intravenous cannulation in the health care of a patient, and accessibility of full text. The exclusion criteria were: editorials, letters, interviews, posters, systematic reviews and no access to full text. The search results obtained in electronic databases were imported into the Mendeley programme and coded with reference to the inclusion criteria. The process of the literature review is displayed in the PRISMA (Preferred Reporting Items for Systematic Reviews and Meta-Analyses) diagram (Moher, et al., 2010) as shown in Figure 1.

\section{The results of the review}

The search produced 1,020 results. We reviewed the topics and abstracts of research articles and identified duplicates. Articles on the use, functions and clinical results of biomedical devices for intravenous cannulation were included in the literature review.

\section{The quality assessment of the review and the description of data processing}

We selected the narrative approach to analyse data as it connects a wide range of research methods. Data synthesis was conducted using the descriptive method, table creation method and content analysis, as recommended by Popay and colleagues (2006). For the evaluation of included research projects, a programme for critical appraisal, CASP (Critical Appraisal Skills Programme), was used. The selection of CASP as the most appropriate tool was influenced by two factors; the fact that this is a frequently used tool in evaluating the quality of articles and that it includes all the most relevant aspects of critical review (reliability, objectivity and validity) (Young \& Solomon, 2009). It is a tool composed of 10 questions and described as suitable for all types of research. Its characteristic is that it clearly defines each individual criterion, which is particularly useful for researchers with little experience. By using the appraisal programme we appraised the articles from low to high quality (Keyko, et al., 2016).

\section{Results}

The literature search was conducted in three databases: CINAHL, MEDLINE and ScienceDirect, and other sources ('grey literature'). The total 
number of search results was 1,020 . After excluding 7 duplicates, 1,013 results remained. Based on the set inclusion criteria (language and time of publication, peer-review, full text access, suitable topic and methodology established based on the title and abstract), 911 articles were excluded. In a detailed review of the remaining 102 fully accessible texts, we excluded a further 85 search results that failed to focus on the topic in great detail. The final result of locating relevant search results was 17 articles, which we then appraised in terms of quality. In all the 17 studies we established medium to high quality. None of the studies was appraised with the highest possible grade nor was any study excluded due to poor quality. Figure 1 shows a diagram of the literature search process, review and inclusion process.

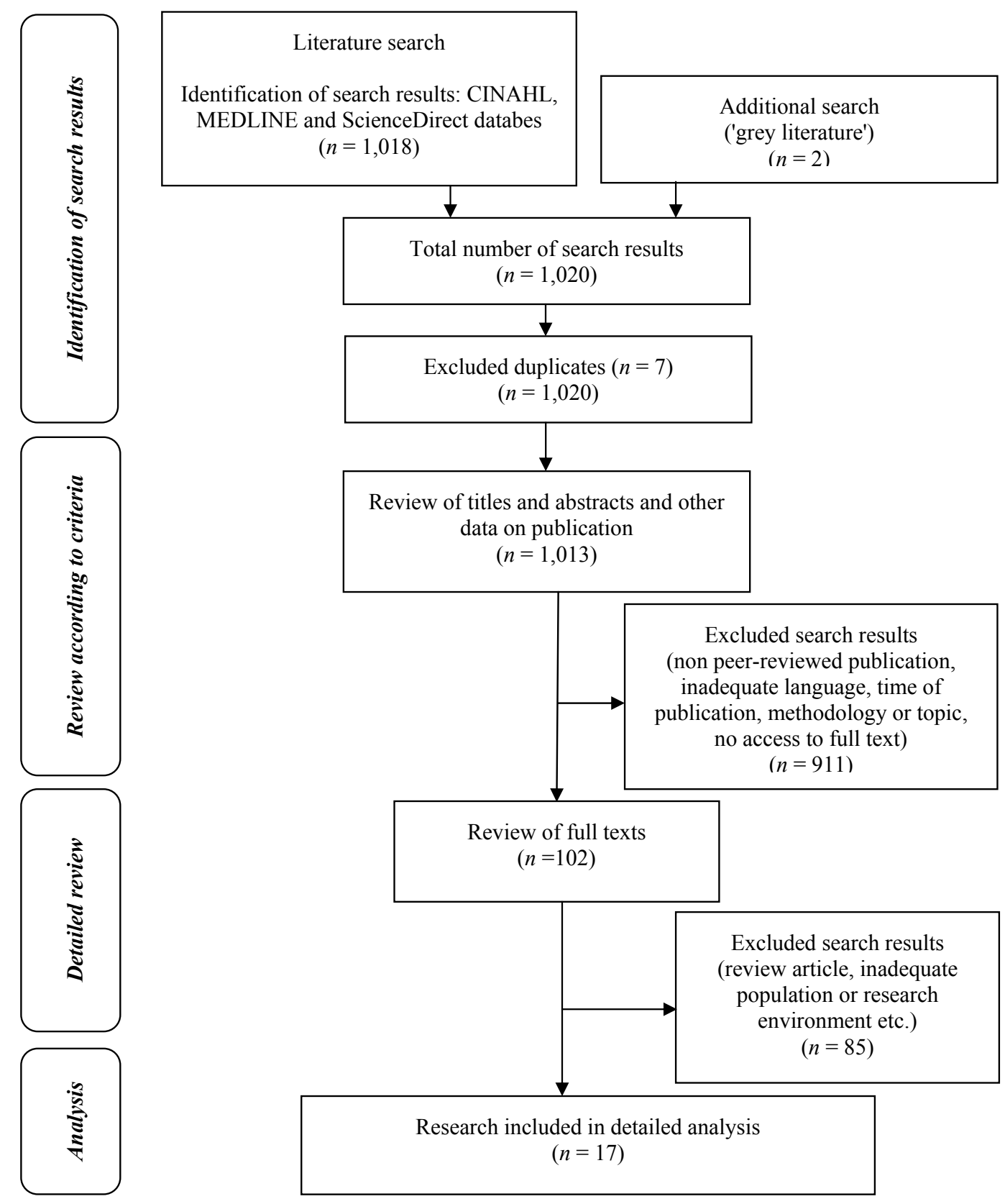

Figure 1: Flowchart of search strategy and literature selection process (PRISMA diagram) Slika 1: Diagram poteka strategije iskanja in izbora literature (diagram PRISMA) 


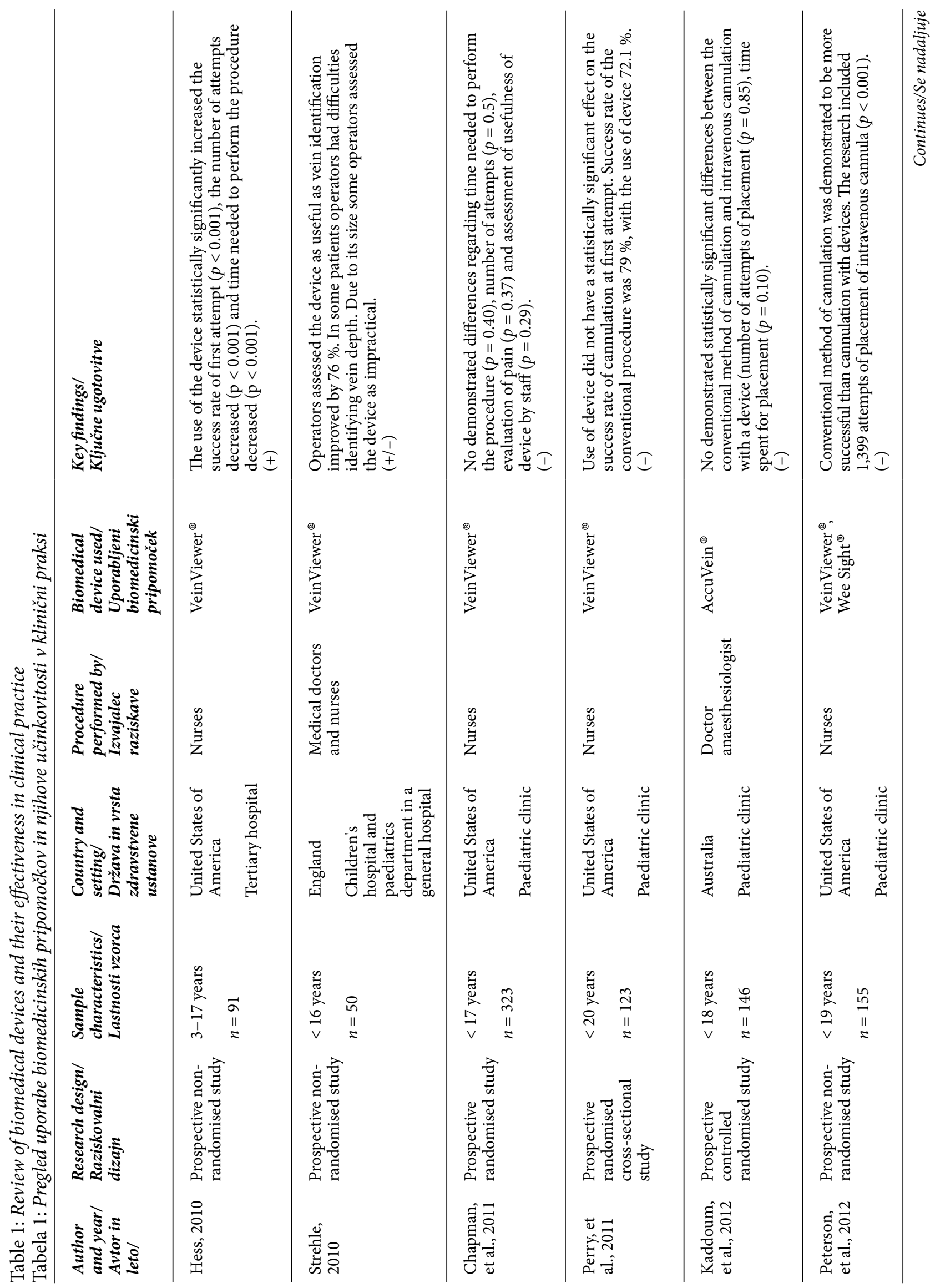




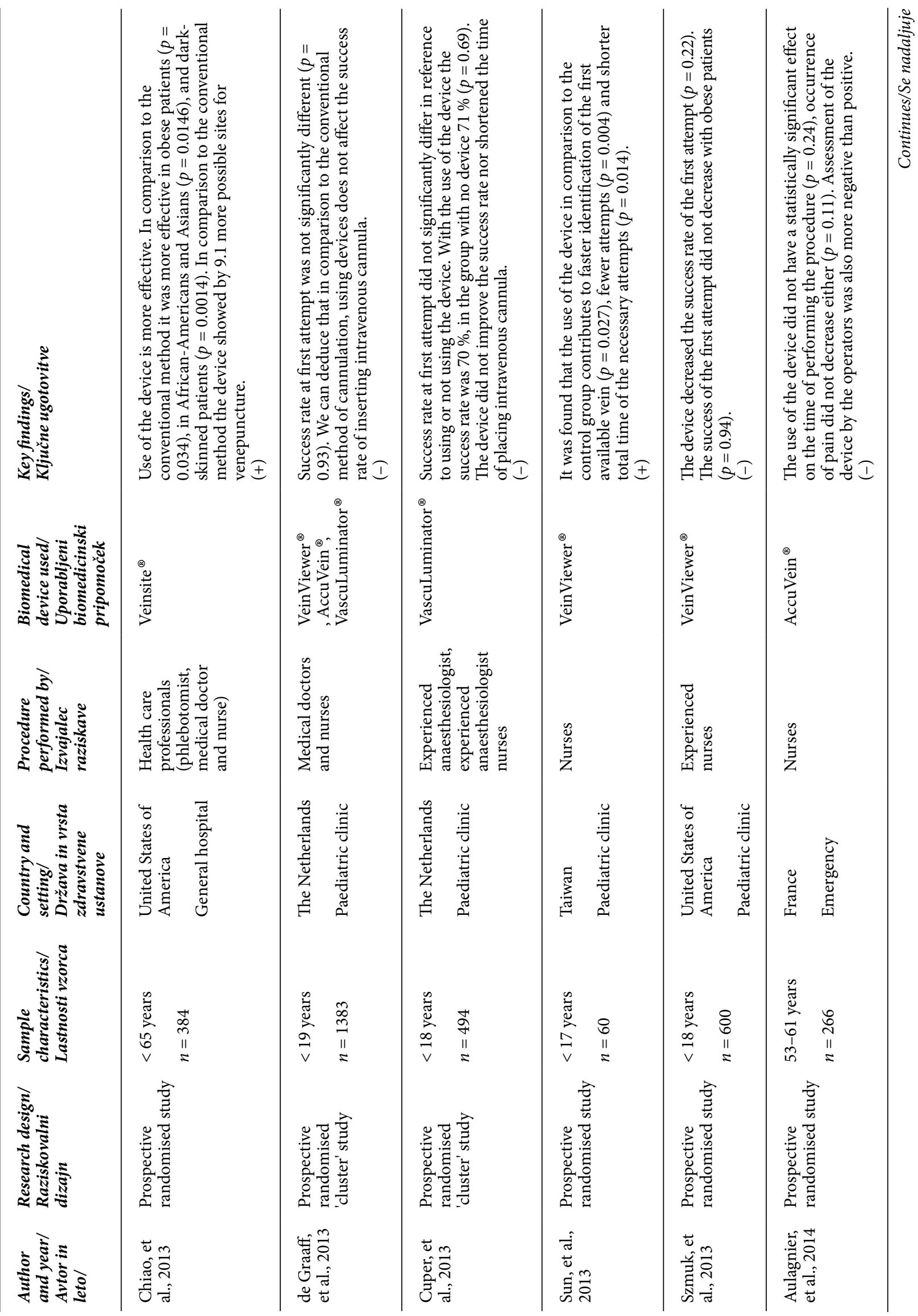




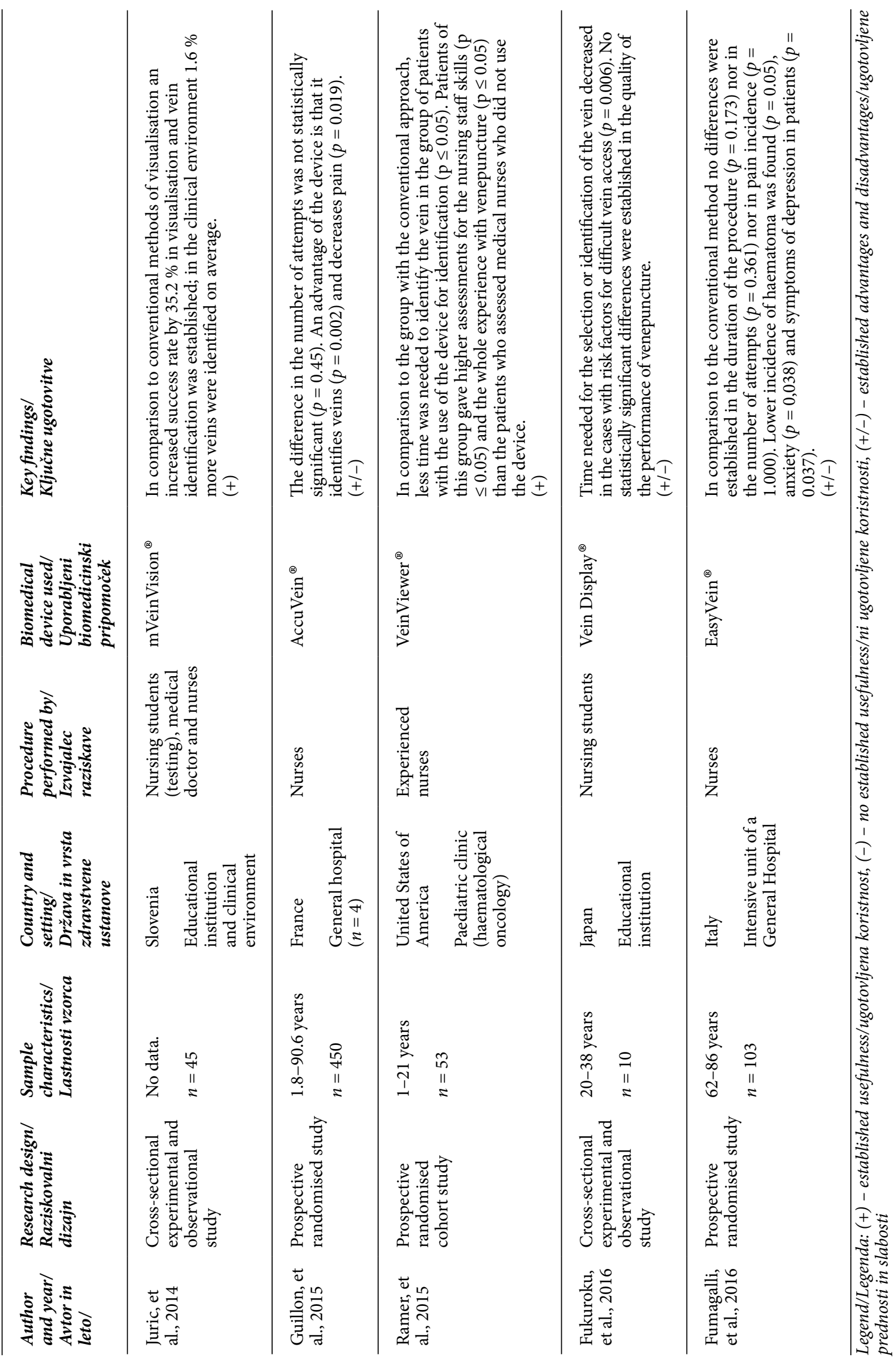




\section{Research characteristics}

17 quantitativestudieswereincluded in thesystematic literature review (12 prospective randomised studies, 3 prospective non-randomised studies and 2 crosssectional experimental and observational studies), which relate to the results of using biomedical devices in clinical practice.

The most frequently used device in the selected studies was VeinViewer ${ }^{\circledR}$. It was used in more than a half of these studies - in nine of them. Next, is AccuVein ${ }^{\circledR}$, used four times, followed by VascuLuminator ${ }^{\circledR}$ used twice and mVeinVision ${ }^{\circledR}$, Wee Sight ${ }^{\circledR}$, Veindisplay ${ }^{\circledR}$ and EasyVein ${ }^{\circledR}$ used once. The use of a biomedical device was most often studied in children's hospitals or paediatric clinics $(n=10)$, significantly less in general and tertiary hospitals $(n=4)$, with only a few studies conducted in emergency care departments ER $(n=$ $1)$ and educational institutions $(n=2)$. The selected studies were conducted in various countries around the world; the United States of America $(n=7)$, the Netherlands $(n=2)$, France $(n=2)$, England $(n=1)$, Australia $(n=1)$, Japan $(n=1)$, Italy $(n=1)$, Taiwan $(n=1)$ and Slovenia $(n=1)$. A detailed description of each study is given in Table 1.

\section{Results of using biomedical devices in clinical practice}

Currently there are three devices available on the market that have obtained marketing authorisation from the American Food and Drug Administration (Juric \& Zalik, 2014). These biomedical devices are: VeinViewer ${ }^{\circledR}$, AccuVein $^{\circledR}$ and VascuLuminator ${ }^{\circledR}$. The first clinical trials using biomedical devices utilising NIR light were published in scientific journals from 2010 onwards. Most of these studies were conducted on a small sample of newborns, children or both, who needed peripheral venous cannula (Hess, 2010; Strehle, 2010; Chapman, et al., 2011; Perry, et al., 2011; Kaddoum, et al., 2012; Peterson, et al., 2012; De Graaff, et al., 2013; Cuper, et al., 2013; Sun, et al., 2013; Szmuk, et al., 2013; Ramer, et al., 2015). The literature contains positive and negative results of using a biomedical device in practice. Eight studies report on its uselessness in a clinical setting, while five studies report on both positive and negative results.

Findings of various authors regarding the uselessness of a biomedical device determined that the device does not significantly decrease patients' pain (Chapman, et al., 2011; Aulagnier, et al., 2014; Fumagalli, et al., 2016). There were also no other established significant differences in the results of using a biomedical device in comparison to the conventional method of intravenous cannulation (Chapman, et al., 2011; Perry, et al., 2011; Kaddoum, et al., 2012; Peterson, et al., 2012; De Graaff, et al., 2013; Cuper, et al., 2013; Aulagnier, et al., 2014).
Two studies (Hess, 2010; Sun, et al., 2013) have found that VeinViewer ${ }^{\circledR}$ may make the venepuncture and intravenous cannulation simpler as a result of an improved success rate at the first attempt and decreased time of conducting the procedure.Sun and colleagues (2013) have found that health care workers spent less time locating the peripheral vein when using an NIR light device in comparison to the control group $(p=$ 0.027 ) and that the use of the biomedical device results in a statistically significant decrease of cannulation attempts $(p<0.001)$ (Hess, 2010). The results of later controlled randomised research projects were less positive. In a randomised study Chapman and colleagues (2011) studied the differences between a group with a conventionally placed intravenous cannula and the group using VeinViewer ${ }^{\circledR}$. There were no established statistical differences between the groups regarding the time of placement of the cannula nor the success rate of the first placement of the intravenous cannula (78 \% success rate in the group with a conventional placement method and a $79 \%$ success rate in the group using a biomedical device; $p=0.53$ ). A randomised cross-sectional study was conducted in the same year, which did not find any advantages in using VeinViewer ${ }^{\circledR}$ in comparison to the conventional method (Perry, et al., 2011) in regards to the success of venepuncture and lower process time. Szmuk and colleagues (2013) additionally demonstrated that the use of VeinViewer ${ }^{\circledR}$ by experienced nursing staff may even lower the success rate of the first attempt of cannulation $(p=0.22)$.

Since 2010 the device AccuVein ${ }^{\circledR}$ has been available in the market. It is a technological device, which is very similar to VeinViewer ${ }^{\circledR}$, but slightly technically simpler, easy to use and mobile. Studies have been conducted since 2012. The study was conducted on patients suffering from hemophillia and showed that the use of AccuVein ${ }^{\circledR}$ had no statistically significant effect on the differences in the number of venepuncture attempts in comparison to the control group with no mentioned illness $(p=0.45)$, however, the identification of veins was significantly better in the group of haemophiliacs $(p=0.002)$. Furthermore, pain was significantly less present $(p=0.019)$ (Guillon, et al., 2015). Also, two studies conducted on the healthy adult population by Aulagnier (2014) and Kaddoum and colleagues (2012) showed no differences found between the venepuncture using $\operatorname{AccuVein}^{\circledR}$ and the common cannulation method in terms of the success rate of intravenous cannulation at first attempt or decrease in the process time.

Further, the authors have found that the reason for the inefficiency of the devices for vein visualisation may be found in the image, as such a device only depicts a two-dimensional image of veins and does not show vein depth, which may lead to overrated estimates of vein sizes (Chiao, et al., 2013; Aulagnier, et al., 2014). Peterson and colleagues (2012) also 
defend the conventional method of intravenous cannulation as experienced nurses are more successful at conventional intravenous cannulation than at cannulation with a biomedical device for vein visualisation. In the study conducted by De Graaff and colleagues (2013), the use of VeinViewer ${ }^{\circledR}$, AccuVein $^{\circledR}$ and VascuLuminator ${ }^{\circledR}$ was compared to conventional venepuncture in a group of patients aged 0-18 years who needed an emergency surgery. The results showed that VeinViewer ${ }^{\circledR}$ (95.3\% patients) and AccuVein ${ }^{\circledR}(94.1 \%)$ were better at vein identification than VascuLuminator ${ }^{\circledR}(89.1 \%)$. There was also no significant difference $(p=0.93)$ regarding the success rate of placing the cannula using the conventional method of venepuncture and the venepuncture technique using the mentioned biomedical devices. The reason for the failure of VascuLuminator ${ }^{\circledR}$ may be the difficulty of visualisation of the insertion site as the operator must be observing the site of insertion on the screen on which the image is projected (De Graaff, et al., 2013). In other two biomedical devices the image is projected onto the patient's skin thus, enabling the insertion of the intravenous cannula on the site or within the projected image (Peterson, et al., 2012).

According to the operators' opinion the main usefulness and advantage of the biomedical devices is that they help to find a new vein (38\%), thus enabling faster localisation (33\%) (Sun, et al., 2013; Juric \& Zalik, 2014; Guillon, et al., 2015; Ramer, et al., 2015; Fukuroku, et al., 2016). In addition, haematoma incidence in patients reduces (Fumagalli, et al., 2016), as well as pain incidence (Guillon, et al., 2015). The use of biomedical devices for vein visualisation proved useful with nursing care students where the selection of the venepuncture site improves significantly, particularly when there are factors related to difficult vein access (Fukuroku, et al., 2016). Juric and Zalik (2014) have also found that a biomedical device for vein visualisation identified $1.6 \%(s=1.8)$ more veins in comparison to the conventional visualisation method.

\section{Discussion}

On the basis of the analysed studies the research question may be answered - we have found that the success rate of the first attempt of inserting the intravenous cannula with biomedical devices was not significantly higher than the success rate of the conventional method of venepuncture in more than one half of the research works (Chapman, et al., 2011; Perry, et al., 2011; Kaddoum, et al., 2012; Peterson, et al., 2012; De Graaff, et al., 2013; Cuper, et al., 2013; Szmuk, et al., 2013; Aulagnier, et al., 2014; Fumagalli, et al., 2016;). On the basis of results analysis we may deduce that the success rate of the first attempt of inserting the cannula depends especially on the experience and skills of the medical nurse. The advantage of using the biomedical device in comparison to the conventional method of venepuncture in terms of a higher success rate at first insertion of cannula was demonstrated only with inexperienced nurses and nursing students (Hess, 2010; Juric \& Zalik, 2014; Fukuroku, et al., 2016). Experienced and educated nurses found the biomedical device useful only in three studies (Chiao, et al., 2013; Sun, et al., 2013, Ramer, et al., 2015), while in other studies experienced nurses assessed the device as useless or the device even lowered the success rate of the first attempt of insertion.

Other health care professionals were also included in studies which attempted to establish the usefulness of a biomedical device for the visualisation of peripheral veins. These were especially medical doctors, paediatricians, anaesthesiologists and phlebotomists. Only two studies report on their positive assessment of the biomedical device. Strehle and colleagues (2010) report that the operators (paediatricians and nurses) assessed the device as useful since vein identification in children improved in $76 \%$ of the cases. Chiao and colleagues (2013) have found that the use of a biomedical device is efficient in obese patients $(p=0.03)$, African-Americans and Asians ( $p$ $=0.01)$, and dark-skinned patients $(p=0.00)$. On the other hand, in reference to the number of attempts of insertion $(p=0.8)$ or the time needed for insertion, $(p=0.10)$ three studies did not demonstrate or find any statistically significant difference between the conventional method of venepuncture and insertion of the intravenous cannula with a biomedical device (Kaddoum, et al., 2012; De Graaff, et al., 2013; Cuper, et al., 2013).

Peterson and colleagues (2012) strongly defend the advantages of the conventional method of inserting the intravenous cannula compared to a biomedical device. In their study they found that the basic methods of palpation and visualisation of the veins are more successful than inserting the intravenous cannula with a biomedical device (VeinViewer ${ }^{\circledR}$, Wee Sight ${ }^{\circledR}$ ). They have therefore found that the use of biomedical devices for vein identification does not necessarily correlate with a higher rate of successfully inserted cannulas. The reason may be that this technology is not three-dimensional - the potential drawback of using the device is the two-dimensional image of veins (Chiao, et al., 2013) and consequently a difficult assessment of vein depth. We should also consider the fact that experienced nurses to a great extent do not need to utilise biomedical devices when inserting the intravenous cannula. Szmuk and colleagues (2013) have found that the use of the biomedical device by an experienced nurse even lowers the success rate of the first attempt at inserting the intravenous cannula. Nevertheless, devices for venous visualisation are a valuable aid to inexperienced nurses and nursing students. The use of biomedical devices for venous visualisation significantly contributes to a greater 
success rate of inserting the intravenous cannula due to a simpler selection of the venepuncture site, but it does not affect the quality of the procedure (Juric \& Zalik, 2014; Fukuroku, et al., 2016). These devices contribute to additional vein identification and shorten the time of the procedure. The results of the use were positive also in the case when risk factors in relation to a more difficult vein visualisation such as patient's obesity or darker skin (Chiao, et al., 2013) were present; when using the devices the medical nurses appeared to be more confident (Ramer, et al., 2015). Nurses should continue to improve their basic abilities of assessing the veins with vein visualisation and palpation. These skills serve as the basis for inserting the cannula, while support technology should be used when this is suitable and necessary (Peterson, et al., 2012).

New mobile NIR devices enable visualisation of several veins in comparison to conventional methods also in cases when veins are not visible or palpable. Several factors affect the visibility of surface veins under standard conditions: infants have adipose tissue distributed more on the surface, which has the effect of a restricted visibility of the subcutaneous tissue. The case is similar with obese people, while in people of Asian descent veins are at first glance less visible due to a smaller cross-sectional diameter of the surface veins (Lamperti \& Pittiruti, 2013). Chiao and colleagues (2013) have found that good vein identification and successful venepuncture result in less tissue damage, lower costs and greater satisfaction of patients. Multiple attempts of venepuncture are connected to an increased incidence of extravasation or vein perforation, which causes haematoma or bleeding and phlebitis. All of this not only increases the fear and suffering of the patient, but also affects patients' trust in nurses (Walsh, 2008). Support technologies are therefore most useful for children and the elderly, dark-skinned people as well as for individuals with risk factors of a more difficult venepuncture. Those nurses that were using the device in comparison to those who were not using it were evaluated as more skilled by patients and were attributed higher grades in relation to the experience of insertion the intravenous cannula (Ramer, et al., 2015). Patient satisfaction should always come first when establishing the peripheral venous access. It is important to be aware that unsuccessful and multiple consecutive attempts of insertion cause patients a certain amount of fear, pain and suffering and that the haematoma incidence decreases with success at first attempt (Guillon, et al., 2015; Fumagalli, et al., 2016). Multiple attempt of insertion directly or indirectly lowers patient satisfaction (due to increased injuries of skin and veins), increases anxiety, lowers self-esteem in nurses and increases costs of the treatment (Kuensting, et al., 2009). If the nursing staff has access to cuttingedge technology, their success rate, satisfaction and productivity may increase, their work conditions improve and patient satisfaction increases. According to the findings of Ramer and colleagues (2015) nurses see the possibility of using biomedical devices as positive and not as an additional responsibility. On the contrary, Aulagnier and colleagues (2014) have found that operators assessed the device more negatively than positively. It should also be considered that the two studies did not deal with the same biomedical device.

Using biomedical devices for vein visualisation is still far from being commonly used in real life and clinical practice. The reason for a low availability of these devices in health care institutions is especially the cost of training and purchase as well as their impracticality, as in life-threatening situations the device often proved to be an obstacle. It should also be taken into consideration that most studies fail to report on how many procedures of inserting the cannula with a biomedical device the operator had to perform before they became skilled. In cannulation, not only the success rate of insertion should be considered but also the time needed for the insertion itself, as these devices are supposed to be of help also in emergency situations, such as securing immediate venous access.

It is interesting that most studies on the usefulness of these devices were conducted with the same assumptions or limitations: exclusive focus on the child population (eleven out of seventeen studies), limited sampling, difficult and unsuitable randomisation, poor standardisation of procedure, too little emphasis of the need of training to use the device, low requirements or no requirements regarding the experience of the operator of the device (Lamperti \& Pittiruti, 2013). In nine studies the manufacturer of the device provided training in the duration from $30 \mathrm{~min}$ to $2 \mathrm{~h}$. Such training was attended by experienced nurses (Perry, et al., 2011; Peterson, et al., 2012; Chiao, et al., 2013; Cuper, et al., 2013; Sun, et al., 2013; Szmuk, et al., 2013) and nursing students (Juric \& Zalik, 2014). Some studies did not mention the experience of nurses, or they were not required to conduct the study (Hess, 2010; Strehle, 2010; Chapman, et al., 2011; Kaddoum, et al., 2012; De Graaff, et al., 2013; Aulagnier, et al., 2014; Guillon, et al., 2015).

Despite the fact that we had access to a large number of search results, there is a possibility that due to certain inclusion criteria we excluded some significant studies. Only fully accessed articles written in the English language were included in the literature review. The fact that the search, review and inclusion of the literature was done by one researcher (first author) is also a limitation.

In order to confirm the advantages of such an approach more studies should be conducted, however, this might be restricted due to the cost of these devices. Further development of technology to ensure access and the simplicity of using biomedical devices will contribute to ensuring the highest standard in patient safety and health care, in the aim to achieve better treatment results of patients worldwide. 


\section{Conclusion}

Intravenous cannulation with using biomedical devices is a useful method for patients with difficult venous access. We have found that the findings of studies vary and point to the fact that the devices do not make any significant clinical benefit if they are used by experienced nurses.

Based on the reviewed literature we cannot claim with all certainty that the devices have a significant effect on easier establishment of peripheral venous access. Here, several factors that contribute to the usefulness or useless of using the devices should be considered: knowledge of anatomy, severely or critically ill patients and children, familiarity with the devices and the possibility of using them. The new approach based on the use of these devices significantly contributes to a decreased haematoma incidence in patients and to decreased feelings of anxiety and inaptitude in inexperienced medical nurses and students in clinical practice. Such an approach provides nursing care students with a comfortable and safe learning environment and enables them to learn about a skill necessary to work successfully in a clinical environment.

\section{Slovenian translation/Prevod v slovenščino}

\section{Uvod}

Vzpostavitev periferne venske poti spada med rutinske invazivne posege in je $\mathrm{v}$ času hospitalizacije izveden pri približno $70 \%$ pacientov (Bernatchez, 2014). Z izrazom periferna venska pot poimenujemo vstavljanje različnih plastičnih igel ali katetrov $\mathrm{v}$ periferno veno. Vzpostavljanje periferne venske poti je ena izmed najpogosteje izvedenih intervencij zdravstvene nege (Bauman, et al., 2009; Walsh, 2008; Juric \& Zalik, 2014) in velja za enega najbolj invazivnih postopkov za paciente, ki iščejo pomoč $\mathrm{v}$ urgentni ambulanti (Bernatchez, 2014). Periferna venska pot je za kritično bolnega pacienta pomembna zaradi potrebe po odvzemu krvi za laboratorijske preiskave, aplikaciji zdravil, tekočin ali parenteralne prehrane, ki jih v danem trenutku potrebuje (Alekseyev, et al., 2012). Uvajanje periferne intravenske (i.v.) kanile je veščina, ki je v kompetencah diplomirane medicinske sestre/ diplomiranega zdravstvenika (Strgar \& Macura Višić, 2013). Pomembno vlogo pri vzpostavljanju venskega dostopa pogosto igra stanje pacienta. Dejavniki tveganja in stanja, povezana s težkimi žilnimi dostopi, vključujejo starost pacienta, izkušnje izvajalca, velikost izbrane i.v. kanile in izbrano mesto vstavljanja (Chinnock, et al., 2007; Sebbane, et al., 2013; Heinrichs, et al., 2013). Obstajajo tudi značilne skupine pacientov, pri katerih je vzpostavljanje periferne venske poti oteženo: pacienti $s$ prekomerno telesno težo ali s perifernimi edemi, pacienti na kemoterapiji, i.v. uporabnikih drog, močno dehidrirani pacienti (Gregg, et al., 2010; Fields, et al., 2014), pacienti temnejše polti (Aulagnier, et al., 2014), otroci in starostniki (Walsh, 2008). Pomanjkljive veščine, nespretnost medicinskih sester ali težak i.v. dostop prispevajo $\mathrm{k}$ večkratnim poskusom vboda (Walsh, 2008). Cuper in sodelavci (2010) ugotavljajo, da so dejavniki tveganja $\mathrm{v}$ praksi sicer dobro poznani, vendar v literaturi zelo skopo opisani. Večja verjetnost za pojav težav pri vzpostavljanju i.v. dostopa obstaja pri otrocih, mlajših od dveh let, in še posebej pri dojenčkih (Chapman, et al., 2011; Heinrichs, et al., 2013). Arbique in sodelavci (2014) menijo, da je za uspešno vstavitev i.v. kanile treba poznati anatomijo ven in endotelijskih celic ter imena in lokacije za venepunkcijo najprimernejših perifernih ven; že pred poskusom vstavljanja je treba vedeti, zakaj je i.v. kanila potrebna in katera vena je za venepunkcijo primerna; poznati je treba tudi zaplete poškodbe vene, povzročene $\mathrm{z}$ aplikacijo zdravil in dovajanimi tekočinami. Ko medicinske sestre razumejo te ključne točke, to znanje pripomore $\mathrm{k}$ zmanjšanju nepotrebne bolečine pri pacientu, povzročene $\mathrm{z}$ več zaporednimi neuspešnimi poskusi vboda, $\mathrm{k}$ zmanjšanju zamud pri medicinski oskrbi, k zmanjšanju porabe dragih biomedicinskih pripomočkov in neproduktivnega časa zdravstvene nege ter $\mathrm{k}$ izboljševanju zdravstvene nege.

$\mathrm{Za}$ dopolnjevanje standardnega postopka slepega uvajanja i.v. kanile so strokovnjaki razvili postopke, ki temeljijo na dodatni vizualizaciji podkožnih ven: uporabo ultrazvočnih naprav, transiluminacijo (presvetljevanje perifernih delov telesa $\mathrm{z}$ drugimi viri svetlobe $-\mathrm{z}$ rdečo ali belo svetlobo) in uporabo biomedicinskih pripomočkov za bližnjo infrardečo spektroskopijo (Walsh, 2008; Juric, et al., 2014). Biomedicinski pripomočki so bili razviti z namenom izboljšati uspešnost venepunkcije in posledično zmanjšati število in obseg negativnih učinkov ob večkratnem oziroma neuspešnem vbadanju ter $\mathrm{z}$ namenom izogibati se frustracijam pri zdravstvenih delavcih $\mathrm{v}$ primeru neuspešno izvedene intervencije. Uporaba biomedicinskih pripomočkov ima v primerjavi $s$ tradicionalno metodo vzpostavljanja perifernega venskega kanala številne prednosti, saj omogoča vstavljanje i.v. kanile $\mathrm{v}$ žile, ki niso vidne niti tipljive, in odpravlja potrebo po vzpostavljanju osrednjega venskega kanala ter posledično zmanjša stopnjo tveganja za okužbo in druge zaplete (Sirk, et al., 2013). Zgodnja prepoznava pacientov $\mathrm{z}$ dejavniki tveganja za oteženo vzpostavljanje venske poti je pomembna zaradi prilagoditve strategije za povečanje uspešnosti oz. zaradi kritične ocene uporabe alternativnih načinov vzpostavljanja i.v. poti oz. venskih pripomočkov (Walsh, 2008; Pagnutti, et al., 2016).

Najstarejša tehnika vizualizacije podkožnih ven se imenuje transiluminacija in vključuje postavitev svetlobnih virov pod ali okoli izbrane okončine (John, 2007). Uporaba bližnje infrardeče spektroskopije (Near Infrared Spectroscopy - NIR) je relativno nov dodatek in vključuje neposredno osvetlitev in vizualizacijo mesta 
venepunkcije (Fukuroku, et al., 2016). Podkožne vene zaradi višje vsebnosti deoksigeniranega hemoglobina skoraj vceloti absorbirajo infrardečo (IR) svetlobovalovne dolžine od $740 \mathrm{~nm}$ do $760 \mathrm{~nm}$, medtem ko arterije zaradi višje vsebnosti oksigeniranega hemoglobina omenjeno svetlobo skoraj v celoti prepuščajo. Omenjeni interval valovnih dolžin spada v t. i. bližnje infrardeče območje, ki v celoti zajema valovne dolžine od $700 \mathrm{~nm}$ do 1400 $\mathrm{nm}$ (Juric, et al., 2014). Na podlagi dostopne literature je na tržišču najti naslednje naprave: VascuLuminator ${ }^{\circledR}$ (Cuper, et al., 2013), VeinViewer ${ }^{\circledR}$ in Wee Sight ${ }^{\circledR}$ (Peterson, et al., 2012), AccuVein ${ }^{\circledR}$ (Kaddoum, et al., 2012), VenoScope ${ }^{\circledR}$, VeinLocator $^{\circledR}$ in VeinLite ${ }^{\circledR}$ (Ernst, 2009) ter Veinsite ${ }^{\circledR}$ (Chiao, et al., 2013).

Našteti biomedicinski pripomočki se razlikujejo $\mathrm{v}$ pristopu vizualizacije krvnih žil in uporabi različnih komponent. Naprava VeinViewer ${ }^{\circledR}$ z NIR-svetlobo analizira kožo in sprejeto sliko projicira nazaj na kožo, pri čemer vene prikazuje kot črne črte na zelenem ozadju (Hess, 2010). Prikazana slika medicinski sestri daje nekakšen zemljevid za delo, da bi bila lahko bolj učinkovita pri vstavljanju i.v. kanile (Lamperti \& Pittiruti, 2013). Prednost uporabe tega pripomočkaje, da pri izvajanju punkcije uporabnik lahko gleda naravnost na mesto vboda, toda normalen pogled mesta vboda je spremenjen in ta tehnika potrebuje obdelavo slike, ki je lahko občutljiva na zunanje vplive (Miyake, et al., 2006). Naprava AccuVein ${ }^{\circledR}$ deluje na podoben način, le da vene projicira kot črne črte na rdečem ozadju (Cuper, et al., 2013). Drugače je pri napravi VascuLuminator ${ }^{\circledR}$, kjer je NIR-svetloba nameščena pod mestom vboda, slika mesta vboda pa se vidi na zaslonu, kjer se vene prikazujejo s črno barvo na svetlem ozadju (Cuper, et al., 2013). Mesto vboda je tako treba opazovati na zaslonu, kamor se projicira preko kamere zajeta slika (Dunn \& Conrad, 2005). Pregled in analiza tržišča sta razkrila, da so v razvoju še druge namenske naprave, ki se osredotočajo na problematiko otežene venepunkcije. Take naprave so še: Evena Eyes-On Glasses ${ }^{\circledR}$ (Medical, 2015), EasyVein ${ }^{\circledR}$ (InSono, 2015), Vein Display ${ }^{\circledR}$ (Fukuroku, et al., 2016) in mVeinVison ${ }^{\circledR}$, ki omogoča vizualizacijo podkožnih ven na mobilnih napravah z operacijskim sistemom Android (Juric \& Zalik, 2014).

\section{Namen in cilji}

Namen članka je predstaviti rezultate sistematičnega pregleda in analize podatkov obstoječih raziskav o razpoložljivih biomedicinskih pripomočkih, ki temeljijo na NIR-svetlobi za iskanje perifernih ven. Izpostavljen je pregled danes dostopnih naprav ter rezultati njihove uporabe $\mathrm{v}$ klinični praksi.

\section{Metode}

Uporabili smo 5-stopenjski metodološki pristop, ki ga opisujeta Higgins in Green (2009). Pristop vključuje oblikovanje in določitev raziskovalnega vprašanja, določanje kriterijev primernosti, iskanje relevantnih dokazov, kritično presojo zbranih podatkov, analizo in sintezo rezultatov. Oblikovali in razvili smo specifično raziskovalno vprašanje $s$ pomočjo pristopa za pregled literature PICO (Population, Intervention, Comparison, Outcome) (Melnyk \& Fineout-Overholt, 2015): V kolikšni meri pri pacientih s težkim žilnim dostopom uporaba sodobnih biomedicinskih pripomočkov, temelječih na bližnji infrardeči spektroskopiji, vpliva na uspešnost prvega poskusa vstavljanja i.v. poti $\mathrm{v}$ primerjavi s klasičnim načinom vstavljanja?

\section{Metode pregleda}

Izvedli smo sistematični pregled literature, ker leta omogoča pridobitev podatkov iz različnih virov in zagotavlja holistično razumevanje obravnavane teme. Iskanje literature je bilo opravljeno $\mathrm{v}$ podatkovnih bazah CINAHL, MEDLINE in ScienceDirects pomočjo različnih kombinacij izbranih iskalnih pojmov $\mathrm{v}$ angleškem jeziku in njihovih sopomenk, povezanih z Boolovima operaterjema AND oz. OR: "devices", "visualization «, "technology«, "cannulation «, "vein «, »nursing care«. Kriterij pri izboru literature je bila objava prispevkov $\mathrm{v}$ angleščini $\mathrm{v}$ časovnem obdobju od leta 2000 do avgusta 2016.

Poleg jezikovne omejitve in omejitve časovnega obdobja objave raziskave so bili glavni vključitveni kriterij še recenzirana objava, kvantitativna osnova raziskav, tematska osredotočenost na opis, uporabo in delovanje biomedicinskih pripomočkov za vzpostavljanje i.v. kanile v zdravstveni oskrbi pacienta in dostopnost polnega besedila. Med izključitvenimi kriteriji so tako bili: uvodniki, pisma, intervjuji, plakati sistematični pregledni članki in nedostopnost polnega besedila. Zadetke rezultatov, dobljenih v elektronskih podatkovnih bazah, smo uvozili v program Mendeley in jih kodirali glede na vključitvene kriterije. Potek pregleda literature je prikazan s pomočjo diagrama PRISMA (Preferred Reporting Items for Systematic Rewievs and Meta-Analyses) (Moher, et al., 2010) in je razviden iz Slike 1.

\section{Rezultati pregleda}

Iskanje je dalo 1020 zadetkov. Pregledali smo naslove in izvlečke raziskav ter identificirali duplikate. $\mathrm{V}$ pregled literature so bili vključeni članki, ki se nanašajo na uporabo, delovanje in klinične rezultate uporabe biomedicinskih pripomočkov za vzpostavitev i.v. kanile.

\section{Ocena kakovosti pregleda in opis obdelave podatkov}

Za analizo podatkov smo izbrali narativni pristop, ki omogoča povezovanje široke palete raziskovalnih metod. Sintezo podatkov smo izvedli s pomočjo 
deskriptivne metode, metode tabeliranja in analize vsebine, ki jih priporočajo Popay in sodelavci (2006). $\mathrm{Za}$ ocenjevanje vključenih raziskav smo uporabili program za kritično vrednotenje CASP (Critical Appraisal Skills Programme). Na izbiro CASP kot najbolj primernega orodja je vplivalo dvoje, in sicer dejstvo, da je to orodje pogosto uporabljeno in sprejeto za ocenjevanje kakovosti člankov in da zajema najpomembnejše vidike kritične presoje (zanesljivost, objektivnost in veljavnost) (Young \& Solomon, 2009). To orodje, ki ga sestavlja 10 vprašanj, je opisano kot primerno za vse tipe raziskav. Zanj je značilno, da jasno opredeljuje vsak posamezen kriterij, kar posebej koristi raziskovalcem z malo izkušnjami. Ocenjene članke smo na podlagi uporabe ocenjevalnega orodja ocenili od nizke do visoke kakovosti (Keyko, et al., 2016).

\section{Rezultati}

Iskanje literature je potekalo $\mathrm{v}$ treh podatkovnih bazah: CINAHL, MEDLINE in ScienceDirect, ter drugih virih (»siva literatura «). Skupno število zadetkov $\mathrm{v}$ vseh podatkovnih bazah in $\mathrm{v}$ drugih virih je bilo 1020.

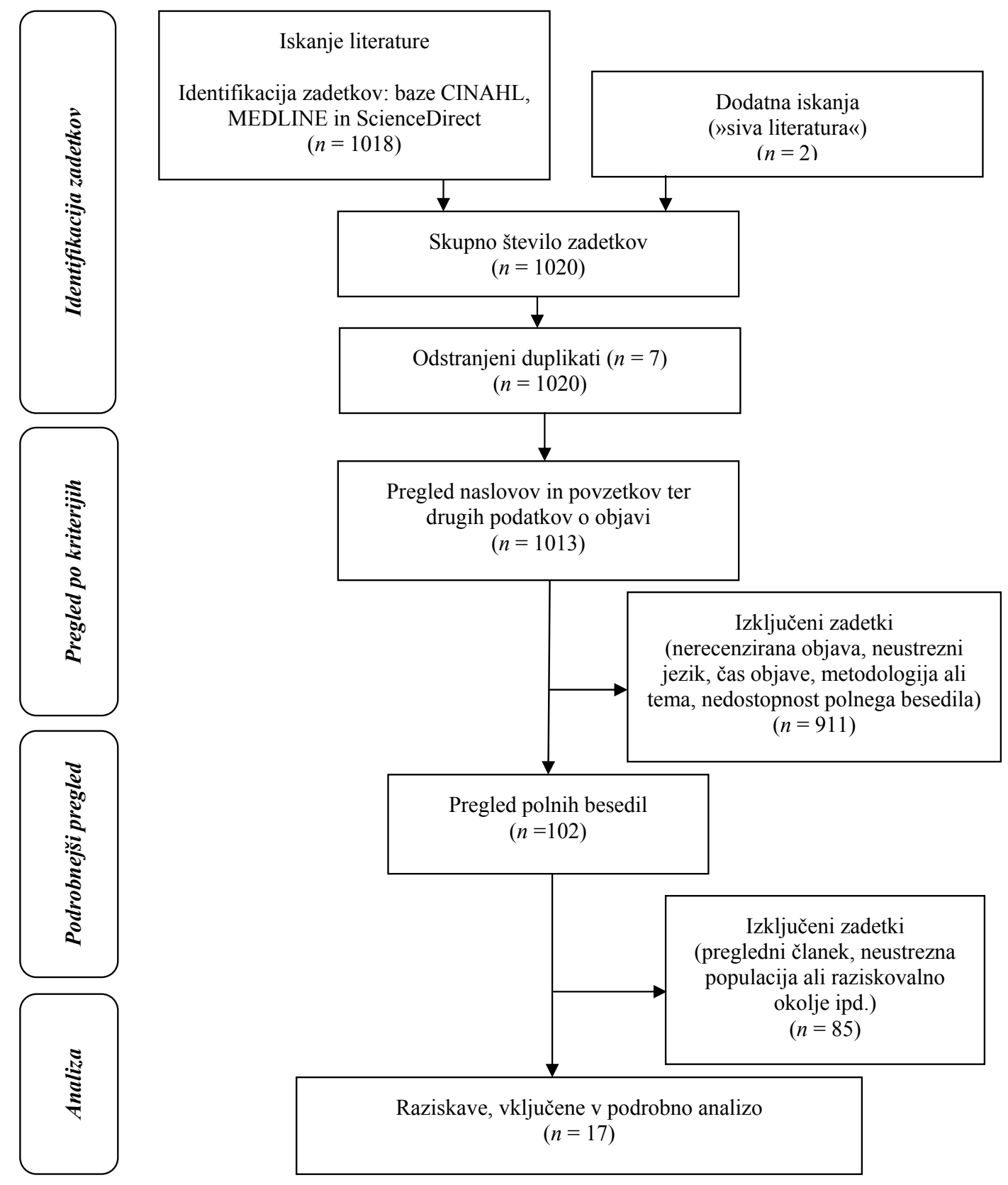

Slika 1: Diagram poteka strategije iskanja in izbora literature (diagram PRISMA)

Figure 1: Flowchart of search strategy and literature selection process (PRISMA diagram) 


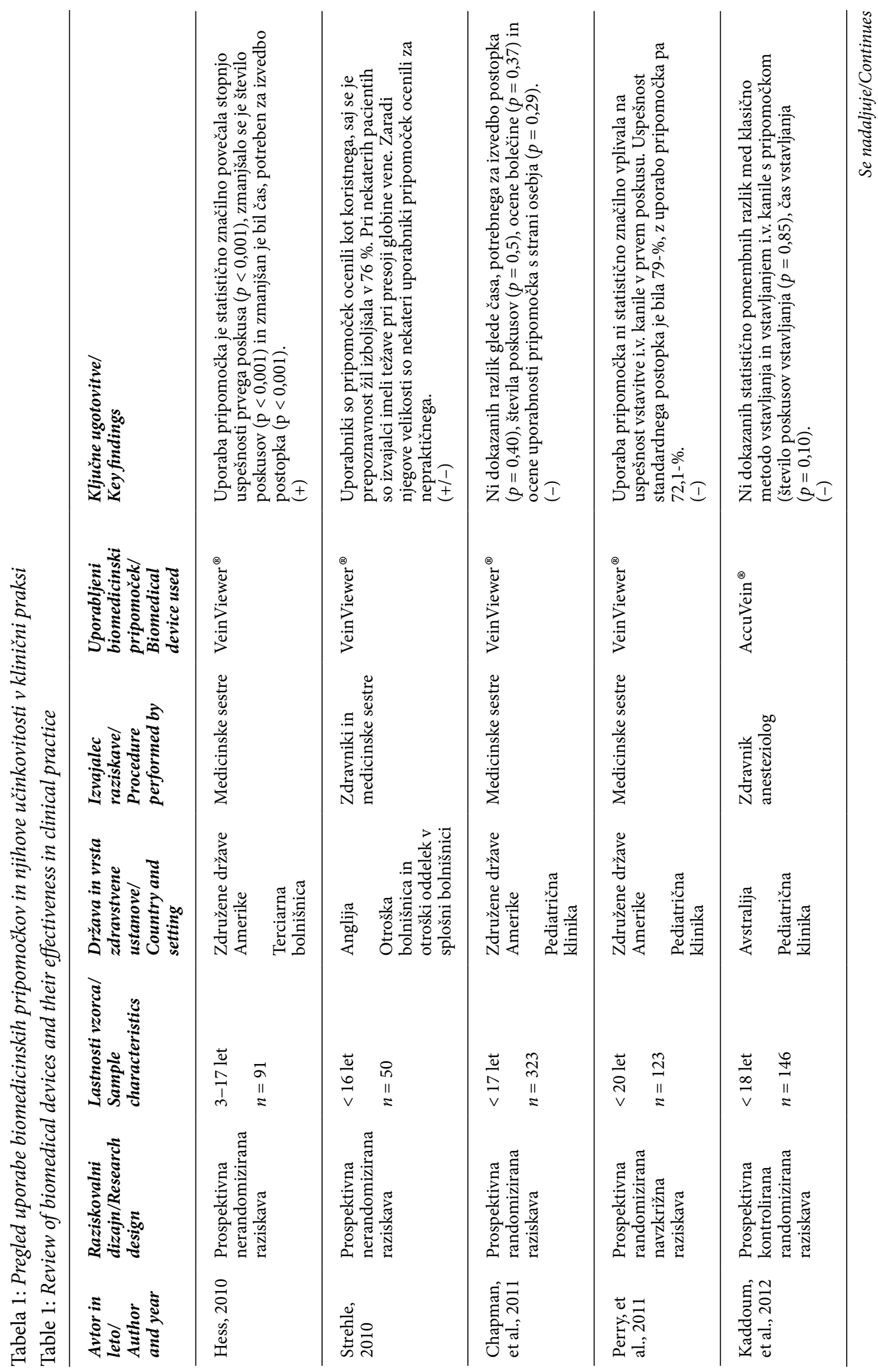




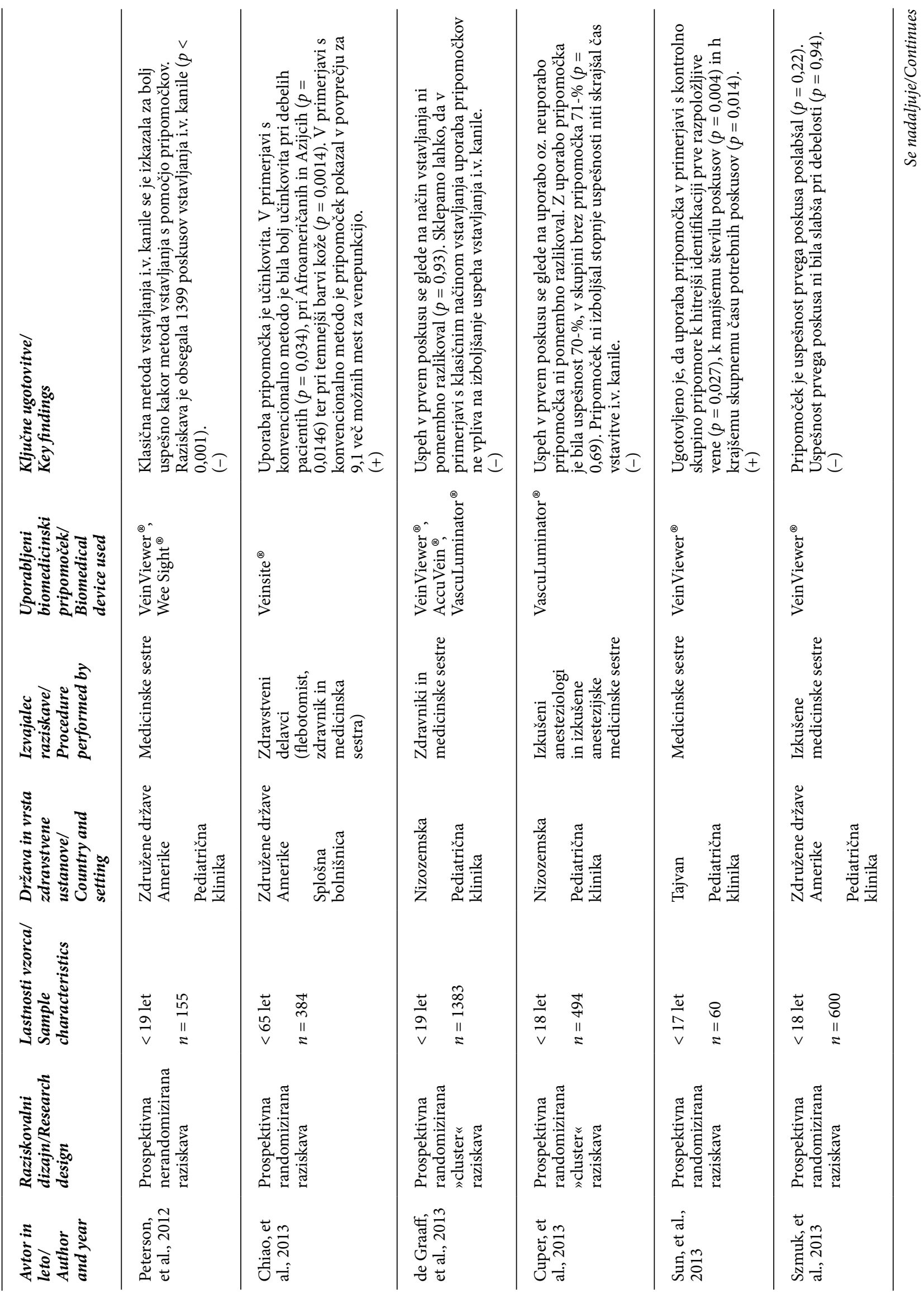




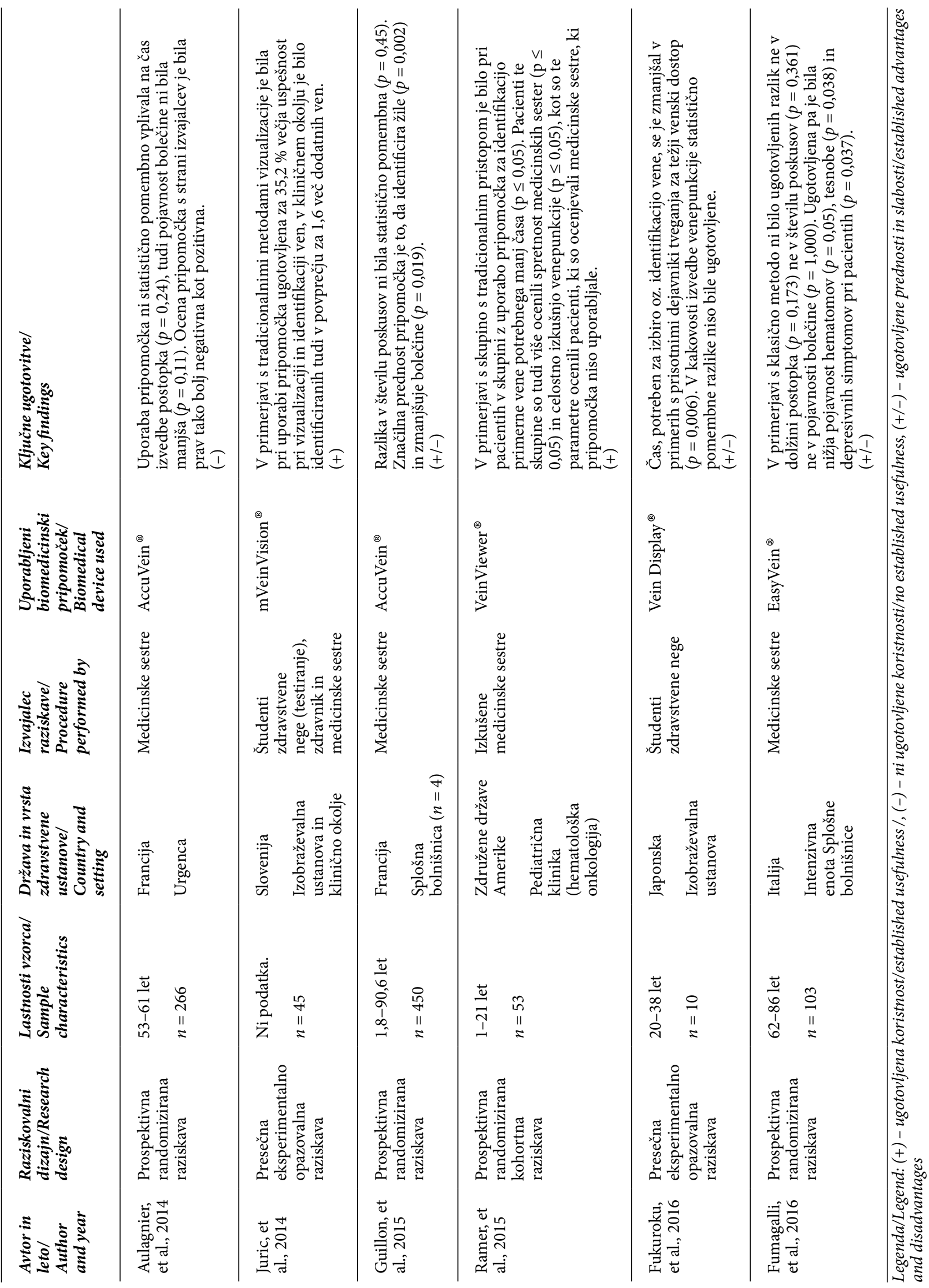


Po odstranitvi 7 duplikatov je ostalo 1013 zadetkov. Od teh smo na podlagi postavljenih vključitvenih kriterijev (jezik in čas objave, recenzija besedila, dostopnost polnega besedila, tematska in metodološka ustreznost, ugotovljeni na podlagi naslova in povzetka) izključili 911 člankov. Po podrobnem pregledu preostalih 102 polno dostopnih besedil smo izključili še nadaljnjih 85 zadetkov, saj se na iskano tematiko niso ozko osredotočali. Končni rezultat iskanja uporabnih zadetkov je 17 člankov, le-te smo ocenili po kakovosti. Pri vseh 17 raziskavah smo ugotovili srednjo do visoko kakovost, nobena od raziskav ni bila ocenjena $\mathrm{z}$ najvišjo možno oceno in tudi nobena ni bila zaradi slabe kakovosti izključena. Slika 1 prikazuje diagram poteka iskanja, pregleda in vključevanja literature.

\section{Karakteristike raziskav}

V sistematičen pregled literature smo vključili 17 kvantitativnih raziskav (12 prospektivnih randomiziranih raziskav, 3 prospektivne nerandomizirane raziskave in 2 presečni eksperimentalno opazovalni raziskavi), ki se navezujejo na rezultate uporabe biomedicinskih pripomočkov v klinični praksi.

$\mathrm{V}$ izbranih raziskavah je najpogosteje uporabljen pripomoček VeinViewer ${ }^{\circledR}$. Uporabili so ga $\mathrm{v}$ več kot polovici teh raziskav, in sicer $\mathrm{v}$ devetih primerih. Sledi AccuVein ${ }^{\circledR}$, ki je bil uporabljen štirikrat, dvakrat so raziskovalci uporabili VascuLuminator ${ }^{\circledR}$ in po enkrat mVeinVision ${ }^{\circledR}$, Wee Sight ${ }^{\circledR}$, Veindisplay ${ }^{\circledR}$ in EasyVein ${ }^{\circledR}$. Uporaba biomedicinskega pripomočka je bila najpogosteje raziskovana $\mathrm{v}$ otroških bolnišnicah oz. pediatričnih klinikah $(n=10)$, precej manj $\mathrm{v}$ splošnih in terciarnih bolnišnicah $(n=4)$, le nekaj raziskav je bilo opravljenih na urgenci $(n=1)$, izobraževalni ustanovi $(n=2)$. Izbrane raziskave so bile izvedene $\mathrm{v}$ različnih državah po svetu, in sicer $\mathrm{v}$ Združenih državah Amerike $(n=7)$, na Nizozemskem $(n=2)$, v Franciji $(n=2)$, Angliji $(n=1)$, Avstraliji $(n$ $=1)$, na Japonskem $(n=1)$, v Italiji $(n=1)$, Tajvanu $(n$ $=1)$ in Sloveniji $(n=1)$. Podroben opis posameznih raziskav je prikazan v Tabeli 1 .

\section{Rezultati uporabe biomedicinskih pripomočkov $v$ klinični praksi}

Trenutno so na tržišču tri naprave, ki so pridobile dovoljenje za uporabo s strani Urada za živila in zdravila ZDA (Juric \& Zalik, 2014). Ti biomedicinski pripomočki so VeinViewer ${ }^{\circledR}$, AccuVein $^{\circledR}$ in VascuLuminator $^{\circledR}$. Prve klinične raziskave o uporabi biomedicinskih pripomočkov, delujočih na podlagi NIR-svetlobe, so bile objavljene $\mathrm{v}$ znanstvenih revijah od leta 2010 naprej. Večina teh raziskav je bila izvedena na majhnem vzorcu novorojenčkov, otrok ali obojih, ki so potrebovali periferno vensko kanilo (Hess, 2010; Strehle, 2010; Chapman, et al., 2011; Perry, et al., 2011; Kaddoum, et al., 2012; Peterson, et al., 2012; De Graaff, et al., 2013; Cuper, et al., 2013; Sun, et al., 2013; Szmuk, et al., 2013; Ramer, et al., 2015). V literaturi je mogoče zaslediti tako pozitivne kot tudi negativne rezultate uporabe biomedicinskega pripomočka v praksi. Osem raziskav poroča o nekoristnosti njegove uporabe $\mathrm{v}$ kliničnem okolju, medtem ko pet raziskav poroča o pozitivnih učinkih in štiri raziskave o pozitivnih in negativnih rezultatih hkrati.

Ugotovitve različnih avtorjev glede nekoristnosti biomedicinskega pripomočka se nanašajo na dejstvo, da pripomoček bistveno ne vpliva na zmanjševanje bolečine pri pacientih (Chapman, et al., 2011; Aulagnier, et al., 2014; Fumagalli, et al., 2016), prav tako tudi ni bilo ugotovljenih nobenih drugih bistvenih razlik pri rezultatih uporabe biomedicinskega pripomočka $\mathrm{v}$ primerjavi s tradicionalnim načinom vstavljanja i.v. kanile (Chapman, et al., 2011; Perry, et al., 2011; Kaddoum, et al., 2012; Peterson, et al., 2012; De Graaff, et al., 2013; Cuper, et al., 2013; Aulagnier, et al., 2014).

Dve raziskavi (Hess, 2010; Sun, et al., 2013) ugotavljata, da VeinViewer ${ }^{\circledR}$ lahko olajša venepunkcijo in vensko vstavljanje kanile na račun izboljšanega uspeha v prvem poskusu in zmanjšanega časa izvedbe postopka. Sun in sodelavci (2013) ugotavljajo, da so v primerjavi s kontrolno skupino zdravstveni delavci pri iskanju periferne vene $\mathrm{z}$ uporabo NIR-svetlobe porabili manj časa $(p=0,027)$ ter da uporaba biomedicinskega pripomočka statistično značilno zmanjšuje število poskusov vboda $(p<0,001)$ (Hess, 2010). Rezultati kasnejših kontroliranih randomiziranih raziskav so bili manj pozitivni. $\mathrm{V}$ randomizirani raziskavi so Chapman in sodelavci (2011) preiskovali razlike med skupino s klasično vstavljeno i.v. kanilo in skupino $\mathrm{z}$ uporabo VeinViewerja ${ }^{\circledR}$. Med skupinama niso ugotovili nobenih statističnih razlik niti glede časa vstavitve niti glede uspešnosti prvega vstavljanja i.v. kanile (78$\%$ uspešnost $\mathrm{v}$ skupini s klasično tehniko vstavljanja in 79-\% uspešnost $\mathrm{v}$ skupini $\mathrm{s}$ biomedicinskim pripomočkom; $p=0,53)$. Še isto leto je bila izvedena randomizirana navzkrižna raziskava, ki glede uspešnosti venepunkcije in skrajšanja procesnega časa podobno ni odkrila nobene prednosti uporabe VeinViewerja ${ }^{\circledR} \mathrm{v}$ primerjavi s tradicionalno metodo (Perry, et al., 2011). Szmuk in sodelavci (2013) so dodatno dokazali, da uporaba VeinViewerja ${ }^{\circledR}$ s strani izkušenih medicinskih sester celo poslabša izid prvega poskusa vstavljanja i.v. kanile $(p=0,22)$.

Od leta 2010 je na tržišču pripomoček AccuVein ${ }^{\circledR}$ - tehnološka naprava, zelo podobna VeinViewerju ${ }^{\circledR}$, vendar nekoliko tehnično poenostavljena, enostavna za uporabo in prenosna. Prve raziskave je moč zaslediti od leta 2012 naprej. Raziskava, opravljena pri pacientih $s$ hemofilijo, je pokazala, da uporaba AccuVeina ${ }^{\circledR}$ ni statistično pomembno vplivala na razlike $\mathrm{v}$ številu poskusov venepunkcije $\mathrm{v}$ primerjavi $\mathrm{s}$ kontrolno skupino brez omenjene bolezni $(p=0,45)$, vendar pa je bila pri skupini hemofilikov bistveno 
boljša identifikacija ven $(p=0,002)$, značilno manj pogosto prisotna je bila tudi bolečina $(p=0,019)$ (Guillon, et al., 2015). Tudi v dveh raziskavah, ki so ju na zdravi odrasli populaciji opravili Aulagnier (2014) in Kaddoum in sodelavci (2012), med venepunkcijo z uporabo AccuVeina ${ }^{\circledR}$ in običajno tehniko vstavljanja kanile glede vpliva na uspešnost vstavljanja i.v. kanile $\mathrm{v}$ prvem poskusu in na skrajšanje procesnega časa ni bilo ugotovljenih nobenih razlik.

Nadalje avtorji menijo, da je razlog za neučinkovitost pripomočkov za vizualizacijo ven moč iskati v prikazu slike, saj taka naprava prikazuje le dvodimenzionalno sliko žil oz. ne prikazuje njene globine, kar vodi v precenjenost velikosti žile (Chiao, et al., 2013; Aulagnier, et al., 2014). Tudi Peterson in sodelavci (2012) zagovarjajo klasično metodo vstavljanja i.v. kanile, saj so izkušene medicinske sestre bolj uspešne pri klasičnem vstavljanju i.v. kanile kot pri vstavljanju le-te $\mathrm{z}$ uporabo biomedicinskih pripomočkov za vizualizacijo ven. V raziskavi, ki so jo opravili De Graaff in sodelavci (2013), so primerjali uporabo VeinViewerja ${ }^{\circledR}$, AccuVeina ${ }^{\circledR}$ in VascuLuminatorja ${ }^{\circledR} \mathrm{s}$ klasično venepunkcijo, in sicer pri skupini pacientov, starih 0-18 let, ki so potrebovali urgentni kirurški poseg. Rezultati so pokazali, da sta VeinViewer ${ }^{\circledR}$ $\left(95,3 \%\right.$ pacientov) in AccuVein ${ }^{\circledR}(94,1 \%)$ žile bolje identificirala kot VascuLuminator ${ }^{\circledR}(89,1 \%)$. Izkazalo pa se je tudi, da glede stopnje uspešnosti nastavitve i.v. kanile med tehniko klasične venepunkcije in tehniko venepunkcije $\mathrm{z}$ uporabo omenjenih biomedicinskih pripomočkov ni bistvene razlike $(p=0,93)$. Razlog za neuspešnost VascuLuminatorja ${ }^{\circledR}$ je moč iskati $\mathrm{v}$ oviranosti normalne inspekcije mesta vboda, saj mora izvajalec mesto vboda opazovati na zaslonu, kamor se slika projicira (De Graaff, et al., 2013). Pri ostalih dveh biomedicinskih pripomočkih se slika projicira na kožo pacienta in tako omogoča vstavljanje i.v. kanile na mestu oz. znotraj projicirane slike (Peterson, et al., 2012).

Po mnenju izvajalcev je glavna koristnost in prednost biomedicinskih pripomočkovv tem, da tak pripomoček pomaga najti novo žilo ( $38 \%)$ in s tem omogoča njeno hitrejšo lokalizacijo (33\%) (Sun, et al., 2013; Juric \& Zalik, 2014; Guillon, et al., 2015; Ramer, et al., 2015; Fukuroku, et al., 2016), pri pacientih pa sta zmanjšana tudi incidenca nastanka hematoma (Fumagalli, et al., 2016) in incidenca bolečine (Guillon, et al., 2015). Uporaba biomedicinskih pripomočkov za vensko vizualizacijo se je pokazala koristna pri študentih zdravstvene nege, pri katerih je bil izbor mesta za venepunkcijo značilno izboljšan zlasti $\mathrm{v}$ primeru prisotnosti dejavnikov, povezanih s težkim žilnim dostopom (Fukuroku, et al., 2016). Tudi Juric in Zalik (2014) ugotavljata, da je uporaba biomedicinskega pripomočka za vensko vizualizacijo $\mathrm{v}$ primerjavi $\mathrm{s}$ klasično vizualizacijsko metodo identificirala za 1,6\% $(s=1,8)$ več ven.

\section{Diskusija}

$\mathrm{Na}$ podlagi analiziranih raziskav odgovarjamo na zastavljeno raziskovalno vprašanje - ugotavljamo, da uspešnost prvega poskusa vstavljanja i.v. kanile z biomedicinskimi pripomočki pri več kot polovici raziskav (Chapman, et al., 2011; Perry, et al., 2011; Kaddoum, et al., 2012; Peterson, et al., 2012; De Graaff, et al., 2013; Cuper, et al., 2013; Szmuk, et al., 2013; Aulagnier, et al., 2014; Fumagalli, et al., 2016;) ni značilno višja od uspešnosti tradicionalne metode venepunkcije. Na podlagi analize rezultatov raziskav sklepamo, da je uspešnost prvega poskusa vstavljanja odvisna predvsem od izkušenosti in spretnosti medicinske sestre. Prednost uporabe biomedicinskega pripomočka $\mathrm{v}$ primerjavi $\mathrm{s}$ tradicionalno metodo venepunkcije, v smislu večje uspešnosti pri prvem vstavljanju i.v. kanile, se je pokazala le pri neizkušenih medicinskih sestrah oz. študentih zdravstvene nege (Hess, 2010; Juric \& Zalik, 2014; Fukuroku, et al., 2016). S strani izkušenih in izobraženih medicinskih sester je bila ugotovljena koristnost biomedicinskega pripomočka samo $\mathrm{v}$ treh raziskavah (Chiao, et al., 2013; Sun, et al., 2013, Ramer, et al., 2015), v preostalih raziskavah so izkušene medicinske sestre pripomoček ocenile kot neuporabnega ali pa je pri njih celo poslabšal uspešnost prvega poskusa vstavljanja.

$\mathrm{V}$ raziskave, ki so ugotavljale koristnost biomedicinskega pripomočka za vizualizacijo perifernih ven, so bili vključeni tudi drugi profili zdravstvenih delavcev. To so bili predvsem urgentni zdravniki, pediatri, anesteziologi in flebotomisti. Le dve raziskavi poročata o njihovi pozitivni oceni uporabe biomedicinskega pripomočka. Strehle in sodelavci (2010) poročajo, da so uporabniki (zdravniki pediatri in medicinske sestre) pripomoček ocenili kot koristen, saj se je prepoznavnost žil pri otrocih izboljšala v 76 $\%$. Chiao in sodelavci (2013) pa ugotavljajo, da se uporaba biomedicinskega pripomočka kot učinkovita izkaže pri debelih pacientih $(p=0,03)$, Afroameričanih in Azijcih $(p=0,01)$ ter pri ljudeh $s$ temnejšo poltjo $(p=0,00)$. Na drugi strani glede števila poskusov vstavljanja $(p=0,8)$ ali časa, potrebnega za vstavitev, $(p=0,10)$ tri raziskave niso dokazale oz. ugotovile nobene statistično značilne razlike med klasično metodo venepunkcije in vstavljanjem i.v. kanile $\mathrm{z}$ biomedicinskim pripomočkom (Kaddoum, et al., 2012; De Graaff, et al., 2013; Cuper, et al., 2013).

Peterson in sodelavci (2012) močno zagovarjajo prednosti klasične metode vstavljanja i.v. kanil v primerjavi z uporabo biomedicinskih pripomočkov. $\mathrm{V}$ raziskavi so odkrili, da so bile osnovne sposobnosti tipanja in vizualizacije ven bolj uspešne kot vstavljanje i.v. kanil s pomočjo biomedicinskih pripomočkov $\left(\right.$ VeinViewer ${ }^{\circledR}$, Wee Sight $\left.{ }^{\circledR}\right)$. Ugotavljajo torej, da uporaba biomedicinskih pripomočkov za identifikacijo ven ne nujno korelira $\mathrm{z}$ višjo stopnjo uspešno vstavljenih i.v. kanil. Razlog je moč iskati v tem, da 
tehnologija ni tridimenzionalna - morebitna omejitev uporabe naprave je prav dvodimenzionalni prikaz žil (Chiao, et al., 2013) in posledično težka ocena njihove globine. V obzir moramo vzeti tudi dejstvo, da izkušene medicinske sestre v veliki meri ne potrebujejo biomedicinskih pripomočkov za vstavljanje i.v. kanile. Szmuk in sodelavci (2013) namreč ugotavljajo, da uporaba biomedicinskega pripomočka s strani izkušene medicinske sestre celo poslabša izid prvega poskus vstavljanja i.v. kanile. Naprave za vensko vizualizacijo so bolj dragocena pomoč neizkušenim medicinskim sestram in študentom zdravstvene nege. Pri študentih uporaba biomedicinskih pripomočkov za vensko vizualizacijo značilno pripomore $\mathrm{k}$ večji uspešnosti vstavitve i.v. kanile zaradi olajšane izbire mesta venepunkcije, ne vpliva pa na kakovost izvedbe postopka (Juric \& Zalik, 2014; Fukuroku, et al., 2016). Te naprave pripomorejo tudi $\mathrm{k}$ dodatni identifikaciji vene in skrajšajo izvedbo postopka. Rezultati uporabe so bili pozitivni tudi v primerih prisotnosti dejavnikov tveganja za težjo vizualizacijo žil, kot sta pacientova debelost in temnejša polt (Chiao, et al., 2013); ob uporabi pripomočkov so medicinske sestre delovale tudibolj kompetentno (Ramer, etal., 2015). Medicinske sestre morajo še naprej izboljševati svoje osnovne sposobnosti ocenjevanja $\mathrm{z}$ vizualizacijo in tipanjem ven. Te veščine služijo kot temelj za vstavljanje i.v. kanile, ob njih pa se uporabljajo podporne tehnologije, kadar je to primerno in potrebno (Peterson, et al., 2012).

Nove prenosne NIR-naprave omogočajo vizualizacijo več žil $\mathrm{v}$ primerjavi s konvencionalnimi metodami tudi v primerih, ko vene niso vidne ali tipljive. $\mathrm{Na}$ vidljivost površinskih ven $\mathrm{v}$ standardnih pogojih vplivajo številni dejavniki: dojenčki imajo bolj površinsko porazdelitev maščobnega tkiva, kar vpliva na omejeno preglednost podkožja, enako je tudi pri debelih pacientih, medtem ko so pri Azijcih žile na prvi pogled manj očitne zaradi manjšega prečnega premera površinskih ven (Lamperti \& Pittiruti, 2013). Chiao in sodelavci (2013) ugotavljajo, da dobro prepoznavanje žile oz. uspešna venepunkcija omogoča manj poškodb tkiva, nižje ekonomske stroške in večje zadovoljstvo pacientov. Večkratni poskusi venepunkcije so povezani $s$ povečano incidenco ekstravazacije oz. žilne perforacije, ki posledično povzroči hematome ali krvavitve in flebitis. Vse to pa ne samo povečuje strah in trpljenje pacienta, ampak vpliva tudi na pacientovo zaupanje medicinskim sestram (Walsh, 2008). Podporne tehnologije so zato najbolj uporabne pri otrocih in starostnikih, pri ljudeh s temnejšo poltjo in pri posameznikih s prisotnimi dejavniki tveganja za težjo venepunkcijo. Pacienti so tiste medicinske sestre, ki so uporabljale pripomoček, $\mathrm{v}$ primerjavi $s$ tistimi, ki naprave niso uporabile, ocenili kot bolj spretne, hkrati so jim dodelili tudi boljše ocene skupne izkušnje vstavljanja i.v. kanile (Ramer, et al., 2015). Pri vzpostavljanju periferne venske poti je vedno treba na prvo mesto postaviti zadovoljstvo pacientov. Treba se je zavedati, da neuspešni in večkratni zaporedni poskusi vbadanja pri pacientih povzročajo določeno stopnjo strahu, bolečine, trpljenja, $\mathrm{z}$ večjo uspešnostjo pri prvem poskusu pa je posledično zmanjšana tudi incidenca nastanka hematoma (Guillon, et al., 2015; Fumagalli, et al., 2016). Večkratno uvajanje neposredno ali posredno povzroča zmanjšano zadovoljstvo pacientov (zaradi povečanega števila poškodb kože in ven), povečano vznemirjenost in zmanjšano samozaupanje medicinskih sester ter povečanje stroškov zdravljenja (Kuensting, et al., 2009). Če pri vzpostavljanju periferne venske poti zdravstvenemu osebju omogočimo uporabo sodobnih pristopov in novosti, lahko povečamo njihovo uspešnost, zadovoljstvo ter produktivnost, omogočimo boljše delovne pogoje ter s tem povečamo pacientovo zadovoljstvo. Po ugotovitvah Ramer in sodelavcev (2015) medicinske sestre možnost uporabe biomedicinskih pripomočkov vidijo $\mathrm{v}$ pozitivni luči in ne kot dodatno obremenitev. Nasprotno pa Aulagnier in sodelavci (2014) ugotavljajo, da so izvajalci pripomoček ocenili bolj negativno kot pozitivno. Upoštevati pa je treba tudi dejstvo, da slednji dve raziskavi nista obravnavali istega biomedicinskega pripomočka.

Uporaba biomedicinskih pripomočkov za vizualizacijo ven je še vedno daleč od resničnega življenja in uporabe v klinični praksi. Vzrok za nizko razpoložljivost teh naprav $\mathrm{v}$ zdravstvenih ustanovah je treba iskati predvsem $\mathrm{v}$ stroških izobraževanja in nakupa ter nepraktičnosti njihove uporabe, saj se pri reševanju življenjsko ogrožajočih stanj pripomoček velikokrat pojavi kot tehnična ovira. Upoštevati je treba tudi, da večina raziskav niti ne poroča, koliko postopkov vstavitve i.v. kanile $\mathrm{z}$ biomedicinskim pripomočkom je moral izvajalec opraviti, da je pri tem postal spreten. Pri vstavljanju i.v. kanile ne smemo upoštevati samo uspešnosti vstavljanja, treba je upoštevati tudi sam čas, potreben za vstavitev, saj naj bi bile te naprave $\mathrm{v}$ pomoč tudi v nujnih primerih, ko je potreben takojšen venski dostop.

Zanimivo je dejstvo, da je večina raziskav o uporabnosti teh naprav opravljenih $\mathrm{z}$ enakimi predpostavkami oz. omejitvami: izključna osredotočenost na otroško populacijo (enajst od sedemnajstih raziskav), omejeno vzorčenje, težavna ali neprimerna randomizacija, slaba standardizacija postopka, premajhen poudarek na potrebi po usposabljanju $\mathrm{z}$ napravo, nizke zahteve ali kar odsotnost zahtev po izkušnjah uporabnika naprave (Lamperti \& Pittiruti, 2013). V devetih raziskavah je bilo $s$ strani proizvajalca zagotovljeno izobraževanje, in sicer po trajanju različno - od 30 minut do 2 uri. Takega izobraževanja so se udeležile izkušene medicinske sestre (Perry, et al., 2011; Peterson, et al., 2012; Chiao, et al., 2013; Cuper, et al., 2013; Sun, et al., 2013; Szmuk, et al., 2013) in tudi študentje zdravstvene nege (Juric \& Zalik, 2014). V 
nekaterih raziskavah izkušnje medicinskih sester niso bile omenjene oziroma za izvedbo raziskave sploh niso bile potrebne (Hess, 2010; Strehle, 2010; Chapman, et al., 2011; Kaddoum, et al., 2012; De Graaff, et al., 2013; Aulagnier, et al., 2014; Guillon, et al., 2015).

Kljub temu da smo dostopali do velikega števila zadetkov, obstaja možnost, da smo zaradi določenih vključitvenih kriterijev izpustili nekatere pomembne raziskave. $\mathrm{V}$ analizo literature so bili vključeni le polno dostopni članki $\mathrm{v}$ angleškem jeziku. Med omejitve vključujemo tudi dejstvo, da je bilo iskanje, pregled in vključevanje literature opravljeno s strani le enega raziskovalca (prva avtorica).

Za potrjevanje prednosti takšnega pristopa je potrebnih še več raziskav, toda njihova izvedba bo tudi $\mathrm{v}$ prihodnje verjetno omejena zaradi cenovno težke dostopnosti pripomočkov. Nadaljnji razvoj tehnologije za zagotovitev dostopnosti in enostavnosti uporabe biomedicinskih pripomočkov bo pripomogel k zagotavljanju najvišjega standarda varnosti pacientov in oskrbe za boljši izid zdravljenja pacientov po vsem svetu.

\section{Zaključek}

Vstavljanje i.v. kanile s pomočjo biomedicinskih pripomočkov je uporabna in koristna metoda za paciente $s$ težkim venskim dostopom. Ugotavljamo, da so izsledki raziskav mešani in kažejo na to, da pripomočki ne doprinesejo nobene pomembne klinične koristi, če jih uporabljajo izkušene medicinske sestre.

$\mathrm{Na}$ podlagi pregledane literature ne moremo $\mathrm{z}$ gotovostjo trditi, da pripomočki bistveno pripomorejo $\mathrm{k}$ lažji vzpostavitvi perifernega venskega dostopa. Pri tem je treba upoštevati več dejavnikov, ki doprinesejo $h$ koristnosti oziroma nekoristnost uporabe pripomočkov: znanje anatomije, težji oz. kritično bolni pacienti in otroci, poznavanje pripomočkov ter možnosti uporabe le-teh. Novi pristop, ki temelji na uporabi pripomočkov, bistveno pripomore $\mathrm{k}$ zmanjšani pojavnosti hematomov pri pacientih ter $\mathrm{k}$ zmanjšanju pojavnosti občutka tesnobe in nesposobnosti pri neizkušenih medicinskih sestrah ter študentih na klinični praksi. Takšen pristop študentom zdravstvene nege zagotavlja udobno in varno učno okolje ter hkrati omogoča, da spoznajo veščino, potrebno za uspešno delo v kliničnem okolju.

\section{Conflict of interest/Nasprotje interesov}

The authors declare that no conflicts of interest exist./Avtorici izjavljata, da ni nasprotja interesov.

\section{Funding/Financiranje}

The study received no funding./Raziskava ni bila finančno podprta.

\section{Ethical approval/Etika raziskovanja}

No approval by the Ethics Committee was necessary to conduct the study due to the selected research methodology./Za izvedbo raziskave glede na izbrano metodologijo raziskovanja dovoljenje ali soglasje komisije za etiko ni bilo potrebno.

\section{Author contributions/Prispevek avtorjev}

The first author conceived the study, defined the search aims, and the methodology used for the identification and analysis of all included data. The first author conducted the literature search and review and the selection of included studies, including data extraction and results. The first author was assisted by the co-author in the writing of the Introduction and data synthesis. Both authors contributed to the writing of Discussion and Conclusion. The co-author greatly contributed to its revision and the final version of the manuscript./Prva avtorica je raziskavo zasnovala, definirala namen in metodologijo za identifikacijo in analizo podatkov. Opravila je tudi iskanje in pregled literature ter izbor vključenih raziskav. Druga avtorica je sodelovala pri pisanju uvoda in sinteze podatkov. Obe avtorici sta prispevali pri pisanju razprave in zaključka. Druga avtorica je z revizijo pomembno pripomogla k dopolnitvam prispevka in k oblikovanju končne različice besedila.

\section{Literature/Literatura}

Alekseyev, S., Byrne M., Carpenter A., Franker C., Kidd C. \& Hulton L., 2012. Prolonging the life of a patient's IV: an integrative review of intravenous securement devices. MEDSURG Nursing, 21(5), pp. 285-292.

PMid:23243786

Arbique, D., Bordelon, M., Dragoo, R. \& Huckaby, S., 2014. Ultrasound-guided access for peripheral intravenous therapy. MEDSURG Nursing, 23(3), pp. 1-15.

Aulagnier, J., Hoc, C., Mathieu, E., Dreyfus, J.F., Fischler, M. \& Le Guen, M., 2014. Efficacy of Accuvein to facilitate peripheral intravenous placement in adults presenting to an emergency department: a randomized clinical trial. Academic Emergency Medicine, 21(8), pp. 858-863.

https://dx.doi.org/10.1111/acem.12437.

PMid:25176152

Bauman, M., Braude, D., \& Crandall, C., 2009. Ultrasoundguidance vs. standard technique in difficult vascular access patients by ED technicians. American Journal of Emergency Medicine, 27(2), pp. 135-140.

https://dx.doi.org/10.1016/j.ajem.2008.02.005.

PMid:19371518 
Bernatchez, S. F., 2014. Care of peripheral venous catheter sites: advantages of transparent film dressings over tape and gauze. Journal of the Association for Vascular Access, 19(4), pp. 256-261. https://dx.doi.org/10.1016/j.java.2014.09.001.

Chapman, L.L., Sullivan, B., Pacheco, A.L., Draleau, C.P. \& Becker, B.M., 2011. VeinViewer-assisted intravenous catheter placement in a pediatric emergency department. Academic Emergency Medicine, 18(9), pp. 966-971.

https://dx.doi.org/10.1111/j.1553-2712.2011.01155.x. PMid:21854488

Chiao, F.B., Resta-Flarer, F., Lesser, J., Ng, J., Ganz, A., PinoLuey, D., et al., 2013. Vein visualization: patient characteristic factors and efficacy of a new infrared vein finder technology. British Journal of Anaesthesia, 110(6), pp. 966-971. https://dx.doi.org/10.1093/bja/aet003.

PMid: 23384732

Chinnock, B., Thornton, S. \& Hendey, G.W., 2007. Predictors of success in nurse-performed ultrasound-guided cannulation. The Journal of emergency medicine, 33(4), pp. 401-405. https://dx.doi.org/10.1016/j.jemermed.2007.02.027. PMid:17976752

Cuper, N.J., De Graaff, J.C., Verdaasdonk, R.M., Van Der Werff, D.B.M. \& Kalkman, C.J., 2010. Predictability of complicated peripheral venous access in children. Pediatric Research, 68, p. 592. https://dx.doi.org/10.1203/00006450-201011001-01198.

Cuper, N.J., Klaessens, J.H.G., Jaspers, J.E.N., de Roode, R., Noordmans, H.J., de Graaff, J.C., et al., 2013. The use of nearinfrared light for safe and effective visualization of subsurface blood vessels to facilitate blood withdrawal in children. Medical Engineering and Physics, 35(4), pp. 433-440.

https://dx.doi.org/10.1016/j.medengphy.2012.06.007.

PMid:22841651

Dunn, M.R., \& Conrad, S., 2005. Utilization of infrared transillumination as an aid for peripheral arterial access. Academic Emergency Medicine, 12(5, Suppl 1), pp. S34-S35.

Ernst, D.J., 2009. Take the guesswork out of venepunctures. MLO: Medical Laboratory Observer, 41(4), pp. 18-20.

PMid:19456062

Fields, J.M., Piela, N.E., \& Ku, B.S., 2014. Association between multiple IV attempts and perceived pain levels in the emergency department. The journal of vascular access, 15(6), pp. 514-518. https://dx.doi.org/10.5301/jva.5000282.

PMid:25198807

Fukuroku, K., Narita, Y., Taneda, Y., Kobayashi, S. \& Gayle, A.A., 2016. Does infrared visualization improve selection of venepuncture sites for indwelling needle at the forearm in secondyear nursing students? Nurse education in practice, 18, pp. 1-9. https://dx.doi.org/10.1016/j.nepr.2016.02.005.

PMid:27235559
Fumagalli, S., Torricelli, G., Massi, M., Calvani, S., Boni, S., Roberts, A.T., et al., 2016. Effects of a new device to guide venous puncture in elderly critically ill patients: results of a pilot randomized study. Aging clinical and experimental research. https://dx.doi.org/10.1007/s40520-016-0547-0

PMid: 26914485

De Graaff, J.C., Cuper, N.J., Mungra, R.A.A., Vlaardingerbroek, K., Numan, S.C. \& Kalkman, C.J., 2013. Near-infrared light to aid peripheral intravenous cannulation in children: a cluster randomised clinical trial of three devices. Anaesthesia, 68(8), pp. 835-845.

https://dx.doi.org/10.1111/anae.12294.

PMid:23763614

Gregg, S.C., Murthi, S.B., Sisley, A.C., Stein, D.M. \& Scalea, T.M., 2010. Ultrasound-guided peripheral intravenous access in the intensive care unit. Journal of Critical Care, 25(3), pp. 514-519. http://dx.doi.org/10.1016/j.jcrc.2009.09.003. PMid:19836193

Guillon, P., Makhloufi, M., Baillie, S., Roucoulet, C., Dolimier, E. \& Masquelier, A.M., 2015. Prospective evaluation of venous access difficulty and a near-infrared vein visualizer at four French haemophilia treatment centres. Haemophilia, 21(1), pp. 21-26. http://dx.doi.org/10.1111/hae.12513

PMid:25335191

Heinrichs, J., Fritze, Z., Vandermeer, B., Klassen, T. \& Curtis, S., 2013. Ultrasonographically guided peripheral intravenous cannulation of children and adults: a systematic review and metaanalysis. Annals of emergency medicine, 61(4), pp. 444-454, el. http://dx.doi.org/10.1016/j.annemergmed.2012.11.014. PMid:23415740

Hess, H.A., 2010. A biomedical device to improve pediatric vascular access success. Pediatric nursing, 36(5), pp. 259-263. PMid:21067078

Higgins, J.P.T. \& Green, S., eds., 2011. Cochrane handbook for systematic reviews of interventions, Version 5.1.0. London: The Cochrane Collaboration.

Available from http://handbook.cochrane.org [20. 9. 2016].

InSono, 2015. InSono Biomedical division EasyVein. Available from http://www.insono.it/wp-content/uploads/presentazione EasyVein.pdf [20.9.2016].

John, J.M., 2007. Transillumination for vascular access: old concept, new technology. Pediatric Anesthesia, 17(2), pp. 197-198. https://dx.doi.wiley.com/10.1111/j.1460-9592.2006.02061.x. PMid:17238901

Juric, S., Flis, V., Debevc, M., Holzinger, A. \& Zalik, B., 2014. Towards a low-cost mobile subcutaneous vein detection solution using near-infrared spectroscopy. Scientific World Journal, p. 365902.

https://dx.doi.org/10.1155/2014/365902.

PMid:24883388 
Juric, S. \& Zalik, B., 2014. An innovative approach to near-infrared spectroscopy using a standard mobile device and its clinical application in the real-time visualization of peripheral veins. BMC Medical Informatics and Decision Making, 14(100), p. 9. https://dx.doi.org/10.1186/s12911-014-0100-z. PMid:25421099

Kaddoum, R.N., Anghelescu, D.L., Parish, M.E., Wright, B.B., Trujillo, L., Wu, J., et al., 2012. A randomized controlled trial comparing the AccuVein AV300 device to standard insertion technique for intravenous cannulation of anesthetized children. Paediatric Anaesthesia, 22(9), pp. 884-889.

https://dx.doi.org/10.1111/j.1460-9592.2012.03896.x.

PMid:22694242

Keyko, K., Cummings, G.G., Yonge, O. \& Wong, C.A., 2016. Work engagement in professional nursing practice: A systematic review. International Journal of Nursing Studies, 61, pp. $142-164$.

https://dx.doi.org/10.1016/j.ijnurstu.2016.06.003.

PMid:27351831

Kuensting, L.L., DeBoer, S., Holleran, R., Shultz, B.L., Steinmann, R.A. \& Venella, J., 2009. Difficult Venous Access in Children: Taking Control. Journal of Emergency Nursing, 35(5), pp. 419-424.

http://dx.doi.org/10.1016/j.jen.2009.01.014.

PMid:19748021

Lamperti, M. \& Pittiruti, M., 2013. II. Difficult peripheral veins: turn on the lights. British Journal of Anaesthesia, 110(6), pp. $888-891$.

https://dx.doi.org/10.1093/bja/aet078.

PMid:23687310

Medical, E., 2015. Evena eyes-on glasses wearable medical computing \& precision IV placement. Available at: http://evenamed.com/wp-content/uploads/2015/11/EvenaEyes-On-Glasses-datasheet-1115.pdf [15. 9. 2016].

Melnyk, B. M. \& Fineout-Overholt, E., 2015. Evidence-based practice in nursing \& healthcare: a guide to best practice. Philadelphia: Wolters Kluwer Health.

Miyake, R.K., Zeman, H.D., Duarte, F.H., Kikuchi, R., Ramacciotti, E., Lovhoiden, G., et al., 2006. Vein imaging: a new method of near infrared imaging, where a processed image is projected onto the skin for the enhancement of vein treatment.

Dermatologic surgery, 32(8), pp. 1031-1038.

https://dx.doi.org/10.1111/j.1524-4725.2006.32226.x

PMid:16918565

Moher, D., Liberati, A., Tetzlaff, J., Altman, D.G. \& PRISMA Group, 2010. Preferred reporting items for systematic reviews and meta-analyses: the PRISMA statement. International Journal of Surgery, 8(5), pp. 336-341.

https://dx.doi.org/10.1016/j.ijsu.2010.02.007.

PMid:20171303
Pagnutti, L., Bin, A., Donato, R., Di Lena, G., Fabbro, C., Fornasiero, L., et al., 2016. Difficult intravenous access tool in patients receiving peripheral chemotherapy: a pilotvalidation study. European Journal of Oncology Nursing, 20, pp. 58-63.

https://dx.doi.org/10.1016/j.ejon.2015.06.008.

PMid:26163026

Perry, A.M., Caviness, A.C. \& Hsu, D.C., 2011. Efficacy of a near-infrared light device in pediatric intravenous cannulation: a randomized controlled trial. Pediatric emergency care, 27(1), pp. 5-10.

https://dx.doi.org/10.1097/PEC.0b013e3182037caf. PMid:21178814

Peterson, K.A., Phillips, A.L., Truemper, E. \& Agrawal, S., 2012. Does the use of an assistive device by nurses impact peripheral intravenous catheter insertion success in children? Journal of Pediatric Nursing, 27(2), pp. 134-143.

https://dx.doi.org/10.1016/j.pedn.2010.10.009.

PMid:22341192

Popay, J., Roberts, H., Sowden, A., Petticrew, M., Arai, L., Rodgers, M., et al., 2006. Guidance on the conduct of narrative synthesis in systematic reviews. A product from the ESRC methods programme Version, 1, p. 92.

Ramer, L., Hunt, P., Ortega, E., Knowlton, J., Briggs, R. \& Hirokawa, S., 2015. Effect of Intravenous (IV) Assistive Device (VeinViewer) on IV access attempts, procedural time, and patient and nurse satisfaction. Journal of pediatric oncology nursing, 33(4), pp. 273-281.

https://dx.doi.org/10.1177/1043454215600425.

PMid:26510643

Sebbane, M., Claret, P.-G., Lefebvre, S., Mercier, G., Rubenovitch, J., Jreige, R., et al., 2013. Predicting peripheral venous access difficulty in the emergency department using body mass index and a clinical evaluation of venous accessibility. The Journal of emergency medicine, 44(2), pp. 299-305.

https://dx.doi.org/10.1016/j.jemermed.2012.07.051. PMid:22981661

Sirk, B., Fekonja, Z., \& Strnad, M., 2013. Identifikacija žil in vzpostavitev periferne venske poti s pomočjo. In: R. Vajd \& M. Gričar, eds. Urgentna medicina: izbrana poglavja 2013. Dvajseti mednarodni simpozij o urgentni medicini. Portorož, Slovenija, 13.-15. junij 2013. Ljubljana: Slovensko združenje za urgentno medicino, pp. 388-389.

Strehle, E. M., 2010. Making the invisible visible: near-infrared spectroscopy and phlebotomy in children. Telemedicine and e-Health, 16(8), pp. 889-893.

https://dx.doi.org/10.1089/tmj.2010.0061.

PMid:20925568 
Strgar, M. \& Macura Višić, N., 2013. Dejavniki, ki vplivajo na uvajanje periferne intravenozne kanile - primerjava med internistično in pediatrično prvo pomočjo v Splošni bolnišnici Jesenice. In: D. Klemenc, et al., eds. Moč za spremembe - medicinske sestre in babice smo v prvih vrstah zdravstvenega sistema: zbornik prispevkov z recenzijo / 9. kongres zdravstvene in babiške nege Slovenije, Brdo pri Kranju, 9. in 10. maj 2013. Ljubljana: Zbornica zdravstvene in babiške nege Slovenije - Zveza strokovnih društev medicinskih sester, babic in zdravstvenih tehnikov Slovenije, pp. 389-395.

Sun, C.Y., Lee, K.C., Lin, I.H., Wu, C.L., Huang, H.P., Lin, Y.Y., et al., 2013. Near-infrared light device can improve intravenous cannulation in critically ill children. Pediatrics and Neonatology, 54(3), pp. 194-197.

https://dx.doi.org/10.1016/j.pedneo.2012.12.012.

PMid:23597539
Szmuk, P., Steiner, J., Pop, R.B., Farrow-Gillespie, A., Mascha, E.J. \& Sessler, D.I., 2013. The VeinViewer vascular imaging system worsens first-attempt cannulation rate for experienced nurses in infants and children with anticipated difficult intravenous access. Anesthesia and analgesia, 116(5), pp. 1087-1092. https://dx.doi.org/10.1213/ANE.0b013e31828a739e. PMid:23492965

Walsh, G., 2008. Difficult peripheral venous access: recognizing and managing the patient at risk. Journal of the Association for Vascular Access, 13(4), pp. 198-203.

https://dx.doi.org/10.2309/java.13-4-7

Young, J.M. \& Solomon, M.J., 2009. How to critically appraise an article. Nature Clinical Practice Gastroenterology \& Hepatology, 6(2), pp. 82-91.

https://dx.doi.org/10.1038/ncpgasthep1331.

PMid:19153565

Cite as/Citirajte kot:

Fekonja, Z. \& Pajnkihar, M., 2017. Use of cutting-edge biomedical devices for intravenous cannulation in the health care of a patient: literature review. Obzornik zdravstvene nege, 51(1), pp. 52-74. https://dx.doi.org/10.14528/snr.2017.51.1.141 